\author{
JAROSŁAW PAŁKA \\ Dom Spotkań z Historia, Warszawa
}

\title{
DZIAŁALNOŚĆ MICHAŁA ŻYMIERSKIEGO W CZASIE OKUPACJI NIEMIECKIEJ W ŚWIETLE AKT MINISTERSTWA BEZPIECZEŃSTWA PUBLICZNEGO
}

Biografia Michała Żymierskiego jest jedną z bardziej zagmatwanych, biorąc pod uwagę nawet niejasność losów innych przywódców komunistycznej Polski ${ }^{1}$. Przed wybuchem I wojny światowej Żymierski działał w Polskich Drużynach Strzeleckich, potem służył w Legionach, dowodził m.in. 2. Pułkiem Piechoty, był też przez pewien czas komendantem Polskiej Organizacji Wojskowej. W okresie wojny polsko-bolszewickiej dowodził 2. Dywizją Piechoty. Wydawało się, że jego kariera rozwija się znakomicie - po ukończeniu École Supérieure de Guerre w Paryżu objął stanowisko zastępcy szefa Administracji Armii, został awansowany do stopnia generała brygady.Jednak będąc odpowiedzialnym za kontrakty dla wojska, dopuścił się poważnych nadużyć finansowych. W czasie przewrotu majowego opowiedział się przeciwko Józefowi Piłsudskiemu.W 1927 r. za malwersacje finansowe został przez sąd zdegradowany i skazany na pięć lat więzienia. Tutaj nawiązał kontakt z komunistami, a po wyjściu z więzienia, w latach 1932-1937 pracował dla wywiadu sowieckiego. Przebywając wówczas w Paryżu, przekazywał służbom sowieckim informacje na temat polskiej armii, a także życia politycznego Polaków na emigracji. Kontakt z nim został przerwany przez centralę w Moskwie z powodu czystek stalinowskich, w trakcie których zlikwidowano znaczną część oficerów prowadzących za granicą sowiecki wywiad agenturalny. Żymierski powrócił do Warszawy w grudniu 1938 r. ${ }^{2}$

${ }^{1}$ Artykuł jest efektem projektu badawczego finansowanego ze środków Narodowego Centrum Nauki w latach 2010-2013 (nr NN 1082063 38) pt. Michał Rola-Żymierski (1890-1989) - biografia polityczna i wojskowa, realizowanego w Instytucie Historii PAN w Warszawie.

${ }^{2}$ Prace nad biografią Żymierskiego prowadził zmarły w 2000 r. Jerzy Poksiński. 
Zdegradowany wojskowy wraz z żoną Zofią i córką Marią zamieszkali w stolicy u swego szwagra, Edwarda Cybulskiego, przy ul. Nowolipki 44. Gdy wybuchła wojna, przeprowadzili się do ciotki żony Żymierskiego, Marceliny Wiśniewskiej, na ul. Potocką na Marymoncie. Żymierski w swoim życiorysie z 1949 r., co zostało potem powtórzone w hagiograficznej biografii z lat osiemdziesiątych ${ }^{3}$, pisał, że rozumiejąc trudną sytuację Wojska Polskiego w 1939 r., zgłosił się już 4 września do szefa Sztabu Głównego, gen. Wacława Stachiewicza, z propozycją utworzenia armii odwodowej, której on, Żymierski, byłby dowódcą. To miało się spotkać ze zdecydowaną odmową Stachiewicza. Trudno zweryfikować, czy w ogóle taka propozycja padła ze strony Żymierskiego. Z powodu wypadków z lat dwudziestych nie mogła ona być jednak poważnie brana pod uwage przez dowództwo wojskowe. Po zakończeniu działań wojennych Żymierscy powrócili na Nowolipki ${ }^{4}$. Ponieważ kamienica, w której mieszkali, znalazła się na terenie wyznaczonego przez Niemców getta, w 1940 r. musieli się przeprowadzić. Zamieszkali przy ul. Wspólnej. Zarówno Żymierski, jak i jego żona w okresie okupacji nigdzie nie pracowali i byli na utrzymaniu szwagra Żymierskiego, Cybulskiego, oraz szwagierki i jej męża - Marii i Karola Kujatów. Kujatowie razem z Cybulskim trudnili się handlem, prowadzili m.in. kiosk z galanterią na bazarze Wielopole przy Halach Mirowskich ${ }^{5}$.

\section{Niemiecki wywiad}

Jednym z podstawowych wątków w śledztwie przeciwko Żymierskiemu w latach pięćdziesiątych była próba ustalenia charakteru jego związków z funkcjonariuszami niemieckiej tajnej policji w czasie okupacji. Informacje na ten temat gromadzono jeszcze przed aresztowaniem Żymierskiego. Józef Światło, który był wicedyrektorem X Departamentu Ministerstwa Bezpieczeństwa Publicznego, zajmującego się zwalczaniem wrogów wewnątrz komunistycznej partii, po ucieczce na Zachód mówił na falach roz-

Efektem tego były m.in. fragmenty biografii Żymierskiego zawarte w monografii pt. TUN. Tatar-Utnik-Nowicki (Warszawa 1992) oraz w serii artykułów opisujących śledztwo i proces Żymierskiego z lat dwudziestych - Sprawa karna Michała Żymierskiego. Część I. Aresztowanie i śledztwo, „Palestra” 2000, 4, Część II. Rozprawa główna, „Palestra” 2000, 5/6, Część III. Wyrok Wojskowego Sądu Okręgowego w Warszawie, ,,Palestra” 2000, 7/8. Zbiory zmarłego profesora zostały przekazane do Archiwum Ośrodka KARTA, znajduje się w nich kilkanaście teczek z materiałami na temat życia komunistycznego marszałka. Autor artykułu korzystał także z tych materiałów.

${ }^{3}$ Marszałek Polski Michał Żymierski, oprac. Wojskowy Instytut Historyczny im. Wandy Wasilewskiej, Warszawa 1983, s. 78-79.

${ }^{4}$ AIPN, 2386/14728, Protokół przesłuchania Edwarda Cybulskiego, 15 III 1953, k. 73.

${ }^{5}$ Ibidem, k. 73-74. 
głośni polskiej Radia Wolna Europa o bardzo intensywnych kontaktach Żymierskiego z gestapo. Powołując się na materiały zgromadzone podczas śledztwa przez funkcjonariuszy Głównego Zarządu Informacji Wojska Polskiego (GZI) w związku z walką w partii z tzw. odchyleniem prawicowo-nacjonalistycznym, opowiadał o tym, że to wywiad sowiecki nakazał Żymierskiemu utrzymywać i rozbudowywać tę współpracę, że z polecenia sowieckiego oddawał w ręce gestapo nie tylko własne raporty, ale także raporty przychodzące z Moskwy. Żymierski miał też regularnie spotykać się z kapitanem Alfredem Spilkerem, który koordynował rozpracowanie i zwalczanie polskiego podziemia w Generalnym Gubernatorstwie ${ }^{6}$. Wątek ewentualnej współpracy Żymierskiego z gestapo nabrał szczególnego znaczenia w połowie 1954 r., gdy zarzuty o jego rzekomej działalności dla wywiadów francuskiego i amerykańskiego oraz przeciwko „ludowej” władzy okazały się nieprawdziwe. Śledczych interesował ten temat od samego początku „rozpracowywania” Żymierskiego, jednak pod koniec 1954 i na początku roku następnego zdecydowano się go rozszerzyć i przesłuchać szczególnie wiele osób, które znały Żymierskiego w czasach okupacji - rodzinę, bliskich znajomych, ale także żołnierzy kontrwywiadu Armii Krajowej czy też uwięzionych po wojnie w Warszawie funkcjonariuszy niemieckiej tajnej policji. Z racji specyfiki tych źródeł wnioski wysnute na ich podstawie należy formułować bardzo ostrożnie. Jednak paradoksalnie, gdyby nie śledztwo z lat pięćdziesiątych, dużo mniej moglibyśmy powiedzieć na temat działalności Żymierskiego w tamtym czasie. Należy także pamiętać, że większość dokumentów, na podstawie których próbowano poniżej odtworzyć losy Żymierskiego w latach 1939-1944, powstała w końcowej fazie jego śledztwa, w latach 1954-1955, w czasie, gdy reżim więzienny był już wyraźnie złagodzony.

27 października 1939 r. do mieszkania na Nowolipkach wkroczyło kilku gestapowców w cywilnych ubraniach. Według zeznań szwagra Żymierskiego, Cybulskiego, domownicy zostali wyprowadzeni do kuchni, natomiast dwóch gestapowców zabrało Żymierskiego do oddzielnego pokoju i tam odbyło z nim półgodzinną rozmowę ${ }^{7}$. Wśród funkcjonariuszy niemieckiej tajnej policji był także Antoni Lewandowski ${ }^{8}$, Polak pracujący dla gestapo,

${ }^{6}$ Z. Błażyński, Mówi Józef Światło. Za kulisami bezpieki i partii, Warszawa 1990, s. 53.

${ }^{7}$ AIPN, 2386/14728, Protokół przesłuchania Edwarda Cybulskiego, 15 III 1953, k. 74. Zeznania zarówno Żymierskiego, E. Cybulskiego, jak i M. Żymierskiej różnią się tylko w szczegółach, jeśli chodzi o fakt przybycia oficerów gestapo do mieszkania przy ul. Nowolipki.

${ }^{8} \mathrm{~W}$ kartotece agentów gestapo prowadzonej w czasie okupacji przez porucznika Stefana Rysia, oficera kontrwywiadu AK, Lewandowski miał figurować jako etatowy pracownik gestapo w stopniu majora, AIPN 2386/14726, Notatka sporządzona przez mjr. Zająca, 1 III 1954, k. 90. 
występujący w czasie najścia na mieszkanie Żymierskiego także jako tłumacz. Lewandowski miał pilnować pozostałych domowników. Gestapo jednak nie aresztowało późniejszego komunistycznego marszałka. Żymierscy w trakcie śledztwa w latach pięćdziesiątych tłumaczyli, że stało się to dzięki wstawiennictwu Lewandowskiego. Ten ostatni miał powiedzieć, iż zna Żymierskiego z wojska w latach dwudziestych - wówczas generał wyświadczył mu jakąś przysługę, za którą był mu bardzo wdzięczny. Zwrócił się do Żymierskiej: „Niech pani nie płacze, męża zostawimy. [--] Niech

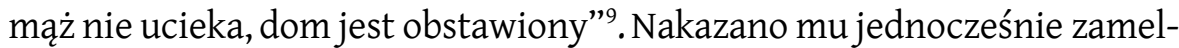
dować się następnego dnia w mieszkaniu Lewandowskiego przy ul. Wilczej 31 pod numerem 6. Tam gestapowcy mieli wypytywać go o dotychczasową jego działalność, o służbę w Wojsku Polskim, pobyt w Paryżu, a także o to, czy brał udział w kampanii polskiej. Po wyjaśnieniach Żymierskiego, złożeniu pisemnej deklaracji o nieuczestniczeniu czynnym w walkach w 1939 r., zwolniono go do domu i nakazano meldować się w mieszkaniu Lewandowskiego co najmniej raz na dwa tygodnie.Jest jednak mało prawdopodobne, aby Żymierskiego nie aresztowano z powodu wstawiennictwa Lewandowskiego, czy też dlatego, że nie brał on czynnego udziału w kampanii 1939 r. Lewandowski nie miał przecież takich możliwości, był tylko niemieckim agentem, natomiast wywiad niemiecki musiał wiedzieć o degradacji i usunięciu Żymierskiego w latach dwudziestych z polskiego wojska. Bardziej prawdopodobne jest to, że grożąc aresztowaniem, gestapo chciało uzyskać od niego jakieś zobowiązania natury konfidencjonalnej czy też politycznej. I od tego momentu datują się stałe kontakty Żymierskiego z Lewandowskim.

Ten ostatni miał być agentem niemieckiego wywiadu jeszcze przed 1939 r. Natomiast w czasie okupacji utrzymywał bliskie i stałe kontakty przede wszystkim z Wolfgangiem Briknerem, który pracował wówczas w Wydziale IV N urzędu policji i Służby Bezpieczeństwa w Warszawie. Brikner dysponował własnymi sieciami wywiadowczymi oraz zajmował się tzw. sprawami szczególnej wagi ${ }^{10}$. Był specjalistą od prowokacyjnych

${ }^{9}$ AIPN, 2386/14728, Protokół przesłuchania Zofii Żymierskiej, 14 III 1953, k. 65.

${ }_{10}$ T. Strzembosz, Akcje zbrojne podziemnej Warszawy 1939-1944, Warszawa 1978, s. 47-49, 415. W zeznaniach Ireny Chmielewicz, która pracowała w warszawskim gestapo w Wydziale (nazywanym referatem) IV A, Brikner funkcjonuje jako szef Wydziału IV N. W takiej też funkcji plasują go Jacek Wilamowski i Włodzimierz Kopczuk, Tajemnicze wsypy. Polsko-niemiecka wojna na tajnym froncie, Warszawa 1990, s. 107. Alfred Otto, w czasie okupacji oficer gestapo, więziony po wojnie w Warszawie i przesłuchiwany przez oficerów GZI, zeznawał, że Brikner od połowy 1940 r. był „kierownikiem referatu $\mathrm{N}$ (Nachrichten), który zajmował się werbowaniem agentury [- - ]. Praktycznie Brikner był więc kierownikiem całej sieci agentury warszawskiego gestapo". AIPN, 2386/14731, Protokół przesłuchania Alfreda Otto, 5 IV 1954, k. 131. 
akcji policyjnych i spraw polskiego podziemia ${ }^{11}$. Lewandowski dzięki kontaktom z gestapo poruszał się po Warszawie autem z osobistym szoferem, był także właścicielem baru przy ul. Marszałkowskiej 61, który stał się „meliną gestapo". Posiadał przestronne i dobrze urządzone mieszkanie. Miał także prowadzić liczne interesy z innym oficerem gestapo - Paulem Wernerem, szefem Wydziału IV A, który zajmował się sprawami wyznaniowymi, m.in. Kościoła protestanckiego ${ }^{12}$. Jednym z głównych działań Wernera były też „sprawy żydowskie” i właśnie w związku z tymi zadaniami Lewandowski miał przekazywać adresy bogatych żydowskich mieszkańców Warszawy, którym - jak zeznawała jedna z pracownic Wernera - „można było zabrać poważne ilości różnych kosztowności"13.

Żymierski oprócz utrzymywania kontaktów z Lewandowskim, prawdopodobnie spotykał się także z Niemcami, oficerami tajnej policji. Podczas składania zeznań w latach pięćdziesiątych przed oficerami GZI w taki sposób opisywał swoje kontakty:

Z Lewandowskim widywałem się przeciętnie dwa razy w miesiącu i tylko w jego mieszkaniu; czasami przychodził on do mnie do domu. [--] Lewandowski kilkukrotnie wyprawiał imieniny swoje. Na imieniny te Lewandowski prosił mnie razem z żoną. Mówił mi, że na przyjęciu będą również oficerowie niemieccy. W związku z tym nie chciałem do niego przyjść. [- - ] Wówczas Lewandowski oświadczył mi wręcz, że jeśli nie przyjdę, to będę tego żałował. Obawiając się zemsty, dwu albo trzykrotnie byłem z żoną na przyjęciach u Lewandowskiego [--]. Rozmowy wówczas toczyły się na tematy ogólne. Oficerowie ci orientowali się, kim jestem ${ }^{14}$.

Natomiast Maria Żymierska zeznawała, że Lewandowski bywał u nich w domu co tydzień lub co dwa tygodnie. Potwierdzała, że zapraszał do

${ }^{11} \mathrm{~W}$ dokumentach śledczych MBP funkcjonuje pod nazwiskiem Birkner, Brikner lub Brükner. Więcej na temat jego działalności patrz: R. Spałek, Z dziejów komunistycznego wywiadu. Casus Bogusława Hrynkiewicza i Mariana Spychalskiego (1940-1944), „Pamięć i Sprawiedliwość" 2008, 1, s. 208-209. Ponadto uważa się, że Brikner brał poważny udział w działaniach, które doprowadziły do mordu w Jedwabnem. Patrz: E. Dmitrów, Oddziały operacyjne niemieckiej Policji Bezpieczeństwa i Służby Bezpieczeństwa a początek zagłady Żydów w Łomżyńskiem i na Białostocczyźnie latem 1941 roku, w: Wokół Jedwabnego, t. 1: Studia, red. P. Machcewicz, K. Persak, Warszawa 2002, s. 289, 327, 350 oraz T. Szarota, Mord w Jedwabnem. Dokumenty, publikacje i interpretacje z lat 1941-2000. Kalendarium, w: Wokót Jedwabnego, t. 1, s. 462-463.

${ }^{12}$ Wcześniej Werner miał zajmować się rozpracowaniem i likwidacją podziemnych organizacji lewicowych.

${ }^{13}$ AIPN, 2386/14731, Protokół przesłuchania Ireny Chmielewicz, 10 IV 1954, k. 139.

${ }^{14}$ AIPN, 2386/14715, Protokół przesłuchania Michała Żymierskiego, 26 III 1955, k. 55-56. 
swojego mieszkania na święta i imieniny. Dwu czy też trzykrotnie Żymierscy byli u Lewandowskiego na letnisku w Zalesiu ${ }^{15}$. O znajomości Żymierskiego z Lewandowskim i ich częstych spotkaniach, mówił także szwagier Żymierskiego, Cybulski. Zeznawał: „Lewandowski mówił, że z ramienia gestapo ma zlecony nadzór nad Żymierskim. W związku z tym zapewniał, że tak długo jak on jest, to Żymierskiemu nic się nie stanie. $Z$ biegiem czasu stosunki z Lewandowskim nabrały, jak gdyby pewnej formy towarzyskiej. Polegało to na tym, że on nas odwiedzał i odwrotnie Żymierski chodził do jego prywatnego mieszkania przy ul. Wilczej" ${ }^{\prime 16}$. Żymierski zeznawał, iż uważał Lewandowskiego za „hochsztaplera”, a dla spokoju przekazywał mu fałszywe informacje, miał się też dzielić tylko „informacjami o ogólnych nastrojach społeczeństwa, dla gestapo miały one nie stanowić żadnej wartości"17. Biorąc pod uwagę wszystkie te zeznania, należy jednoznacznie stwierdzić, że przyszły komunistyczny marszałek utrzymywał bliskie i regularne kontakty z niemieckim agentem.

Inni przesłuchiwani w latach pięćdziesiątych przez śledczych GZI potwierdzali fakt prowadzenia przez Żymierskiego częstych rozmów z agentem gestapo.Zeznawali w ten sposób Anita Küchenbacker, agentka gestapo z czasów okupacji, oraz jej mąż, także współpracownik gestapo, Teodor Moszczeński - oboje skazani po wojnie za współpracę z Niemcami i przebywający w więzieniu, a także partnerka Lewandowskiego z czasów okupacji Maria Cieszkowska czy też Władysław Wasilewski, pracownik baru, którego właścicielem był Lewandowski ${ }^{18}$. Żymierski zaprzeczał, jakoby znał nazwiska wyżej postawionych oficerów niemieckiej tajnej policji. Nie przyznawał się także do rozmów - oprócz kontaktów z Lewandowskim - zjakimikolwiek innymi funkcjonariuszami gestapo,którym miałby przekazywać jakieś informacje ${ }^{19}$. Tymczasem Cieszkowska miała go dwukrotnie widzieć w towarzystwie Wernera w domu Lewandowskiego, widziała ponadto jakieś rękopisy przekazywane przez Żymierskiego ${ }^{20}$. O spotkaniach Żymierskiego z Wernerem zeznawali także Küchenbacker i Moszczeński ${ }^{21}$.

${ }^{15}$ AIPN, 2386/14728, Protokół przesłuchania Zofii Żymierskiej, 15 III 1953, k. 76.

16 AIPN, 2386/14728, Protokół przesłuchania Edwarda Cybulskiego, 15 III 1953, k. 74.

${ }^{17}$ AIPN, 2386/14715, Protokół przesłuchania Michała Żymierskiego, 26 III 1955, k. 55-56.

${ }^{18}$ AIPN, 2386/14718, Notatka służbowa z przeglądu posiadanych dokumentów na Żymierskiego Michała s. Wojciecha, 22 XII 1954, k. 208.

${ }^{19}$ AIPN, 2386/14715, Protokół przesłuchania Michała Żymierskiego, 26 III 1955, k. 55-56.

${ }^{20}$ Ponadto Cieszkowska zeznawała, że widziała Lewandowskiego i Żymierskiego w towarzystwie „wyższego urzędnika berlińskiego gestapo barona von Solisch”. Patrz: AIPN, 2386/14718, Notatka służbowa z przeglądu posiadanych dokumentów na Żymierskiego Michała s. Wojciecha, 22 XII 1954, k. 208.

${ }^{21}$ AIPN, 2386/14726, Notatka sporządzona przez mjr. Zająca, 1 III 1954, k. 88-89. 
Kontakty Żymierskiego z Lewandowskim trwały od jesieni 1939 r. do połowy 1942 r., do czasu aresztowania tego ostatniego i uwięzienia go na Pawiaku ${ }^{22}$. Nie znamy przyczyn takiego zwrotu w losach Lewandowskiego, nie mamy żadnych przekazów, które mogłyby świadczyć o tym, że nastąpiło to z powodu jakiejś współpracy agenta gestapo także z polskim podziemiem ${ }^{23}$. Mogły to być porachunki wśród oficerów tajnej policji, porachunki wewnątrz agentury, których ofiarą padł Lewandowski, może stały za tym jakieś względy finansowe. W każdym razie Lewandowski we wrześniu 1942 r. został przewieziony do obozu koncentracyjnego w Auschwitz i na początku następnego roku stracony ${ }^{24}$. Żymierski po aresztowaniu Lewandowskiego miał wyrażać obawę, czy nie zostanie uwięziony, i zaczął się ukrywać. Tak zeznawał szwagier Żymierskiego. Także żona przyszłego komunistycznego marszałka zeznawała, że od czasu aresztowania Lewandowskiego Żymierski ukrywał się, nie precyzując jednocześnie, na czym miało to polegać ${ }^{25}$. Być może zaczął się posługiwać innym nazwiskiem, na które wystawiono mu podrobione dokumenty. Takimi dokumentami na pewno legitymował się od sierpnia 1943 r., a więc rok po aresztowaniu Lewandowskiego ${ }^{26}$. Nie mamy żadnych informacji, aby stało się to wcześniej.

${ }^{22}$ AIPN, 2386/14718, Notatka służbowa z przeglądu posiadanych dokumentów na Żymierskiego Michała s. Wojciecha, 22 XII 1954, k. 208.

${ }^{23}$ S. Ryś, w czasie okupacji zastępca szefa Wydziału Bezpieczeństwa i Kontrwywiadu II Oddziału KG AK, twierdził, że kontrwywiad AK próbował wykonać wyrok na Lewandowskim za jego aktywną działalność dla niemieckiego wywiadu, AIPN, 2386/14731, Protokół przesłuchania Stefana Rysia, 20 III 1954, k. 107-108. Informacje zgodne z faktami przeplatają się tutaj z nieprawdziwymi. Ryś na przykład mówił o tym, że wywiad AK miał wiadomości, jakoby Lewandowski opuścił Warszawę, ponieważ został wysłany przez Niemców do Afryki, by prowadził tam działalność wywiadowczą wśród jednostek Polskich Sił Zbrojnych na Zachodzie.

${ }^{24}$ Antoni Łukasz Lewandowski urodzony w $1900 \mathrm{r}$. został deportowany do KL Auschwitz 22 września 1942 r. z Pawiaka (numery 64779-64853). 11 stycznia 1943 r. osadzono go w areszcie obozowym w podziemiach Bloku 11 na polecenie wydziału politycznego (obozowa placówka gestapo). Rozstrzelano go 13 lutego 1943 r. pod Ścianą Śmierci. Archiwum Państwowego Muzeum Auschwitz-Birkenau, D-Au I-2/33. Księgi zgonów, t. 6, k. 144, akt zgonu nr 7646/1943 więźnia A.Ł. Lewandowskiego; D-Au I-3/1. Książka bunkra, t. 1b, k. 108; Księga Pamięci. Transporty Polaków z Warszawy do KL Auschwitz 1940-1944, red. F. Piper, I. Strzelecka, t. 1, Warszawa-Oświęcim 2000, s. 566.

${ }^{25}$ AIPN, 2386/14728, Protokół przesłuchania Edwarda Cybulskiego, 15 III 1953, k. 74 oraz AIPN, 2386/14728, Protokół przesłuchania Zofii Żymierskiej, 15 III 1953, k. 76.

${ }^{26} \mathrm{~W}$ sierpniu $1943 \mathrm{r}$. Żymierski zaczął posługiwać się kenkartą wystawioną na Władysława Zwolińskiego, urodzonego w styczniu 1890 r. w Łowiczu. Z zawodu miał być buchalterem. Kenkarta nie została wydana z powodu konspiracyjnej działalności w Gwardii Ludowej. Fałszywy dokument wystawił w Łowiczu Stanisław Ścibura, który należał do konspiracyjnego Wojskowego Korpusu Służby Bezpieczeństwa, a więc policji wojskowej dowodzonej przez Pawła Piskozuba, podległej Ludwikowi Muzyczce 
Według materiałów zgromadzonych przez oficerów GZI kontakty Żymierskiego z gestapo nie ustały wraz z aresztowaniem Lewandowskiego. Miały o tym świadczyć przechwycone przez komunistyczny wywiad wojskowy dokumenty kontrwywiadu Komendy Głównej AK oraz zeznania oficerów tej służby przesłuchiwanych przez oficerów GZI. Więziony w czasach stalinowskich por. Stefan Ryś zeznawał, że kontrwywiad wiedział o kontaktach Żymierskiego z Lewandowskim, ponadto Żymierski miał zostać zarejestrowany w prowadzonej przez niego kartotece agentów niemieckich ${ }^{27}$. Pomimo usilnych poszukiwań, w materiałach zgromadzonych przez pracowników MBP kartoteki Żymierskiego nie udało się odnaleźć, jednak w kartotekach innych niemieckich agentów pojawiała się jego osoba ${ }^{28}$. Ryś zeznawał także o kontaktach Żymierskiego z innymi współpracownikami niemieckiej tajnej policji doktorem Stefanem Onyszkiewiczem i Arturem Staszauerem vel Józefem Dalderem. Ten ostatni, będąc oficerem Oddziału V KG AK, okazał się także agentem niemieckiego wywiadu. W prowadzonym przez niego „Barze za kotarą" przy ul. Mazowieckiej gościło wielu niemieckich tajnych współpracowników, funkcjonariuszy gestapo. W barze spotykał się ze Staszauerem i prowadził z nim ,jakieś interesy” także Żymierski. Spotykać się tam miał także $\mathrm{z}$ „senatorem Fichną, Tabakiewiczem i Sikorskim Janem" 29 . Po aresztowaniu przez gestapo jednego z oficerów AK, co stało się za sprawą Staszauera, sąd Polskiego Państwa Podziemnego zdecydował się wydać na niego wyrok śmierci. W jednym z wielu punktów uzasadnienia wyroku padło nazwisko Żymierskiego: „Tymcza-

z AK. Piskozub był też współpracownikiem Żymierskiego ze Związku Podoficerów Rezerwy. Potwierdzałoby to fakt działalności Żymierskiego w kilku organizacjach jednocześnie. S. Ścibura przebywał w latach pięćdziesiątych w więzieniu w Łodzi. AIPN, 2386/14727, Raport w sprawie Ścibury Stanisława, 2 IV 1951, k. 164.

${ }^{27}$ AIPN, 2386/14730, Protokół przesłuchania Stefana Rysia, 22 III 1954, k. 333-334. A.K. Kunert, Słownik biograficzny konspiracji warszawskiej 1939-1944, t. 1, Warszawa 1987, s. 136-137.

${ }^{28}$ Kartotekę taką w czasach okupacji prowadził por. S. Ryś. W 1945 r. znalazła się ona w posiadaniu MBP. Przeprowadzone w MBP dochodzenie w sprawie odnalezienia dokumentów Żymierskiego z tej kartoteki nie przyniosło spodziewanych rezultatów. Kpt. Zając w piśmie do płk. Skulbaszewskiego informował, że pracownik Departamentu I MBP, który miał pieczę nad tą kartoteką, napisał w raporcie: „on [pracownik Departamentu I MBP - J.P.] karty Żymierskiego nie widział i nie wie, czy ona była w kartotece. Wie tylko, że w innych kartach powoływano się na jego [Żymierskiego - J.P.] kartę". AIPN, 2386/14726, Raport, 25 II 1954, k. 80-81.

${ }^{29}$ Pewnym wytłumaczeniem tej znajomości miałby być fakt, że Staszauer w czasie I wojny światowej podobnie jak Żymierski służył w II Brygadzie Legionów. Ten powód oczywiście nie wykluczałby tego, że podczas ich spotkań nie wchodziły w grę sprawy wywiadowcze. AIPN, 2386/14718, Notatka służbowa o wynikach śledztwa ws. Żymierskiego Michała, 21 III 1955, k. 280. 
sem w sierpniu 1942 roku pojawiają się pierwsze nieśmiałe pogłoski, że Staszauer oraz Żymierski i Fichna - są podejrzani o współpracę z GO [gestapo - J.P.] (ci ostatni najprawdopodobniej z racji kontaktowania się ze Staszauerem)" ${ }^{30}$.

8 października 1943 r. do baru wkroczył pododdział 993/W dowodzony przez por. Stefana Matuszczyka. Wywiązała się regularna strzelanina, w wyniku której zginęło 10 agentów i funkcjonariuszy gestapo, a także cztery przypadkowe osoby, grupa bojowa AK miała dwóch rannych. Zarówno Ryś, któremu podlegał bezpośrednio Matuszczyk, jak i porucznik Juliusz Wilczur-Garztecki, zastępca szefa Referatu Politycznego Kontrwywiadu KG AK, który „rozpracowywał” Polską Partię Robotniczą, zeznawali w latach pięćdziesiątych, że dosłownie pół godziny przed rozpoczęciem akcji bar opuścił Żymierski. Takie informacje przekazał im Matuszczyk ${ }^{31}$. Żymierski nie był celem ataku, jednak mógł wówczas stracić życie.

O współpracy Żymierskiego z agentami niemieckiego wywiadu zeznawał także w latach pięćdziesiątych więziony w Polsce Alfred Otto, w czasie okupacji kierownik Wydziału IV B, który zajmował się zwalczaniem działalności AK i Delegatury Rządu na Kraj. Sprawa wydaje się dosyć sensacyjna i mało wiarygodna, znów też opiera się na relacjach osób trzecich. Niedługo przed wybuchem powstania warszawskiego Otto wszedł w posiadanie „Biuletynu Informacyjnego”, w którym znalazła się wiadomość o tym, że gen. „Rola” objął dowództwo wojsk polskich walczących przy boku Armii Czerwonej. Poszedł z tą informacją do kapitana A. Spilkera, który koordynował rozpracowanie i zwalczanie polskiego podziemia w Generalnym Gubernatorstwie. W gabinecie Spilkera obecny był wówczas Brikner. Ten ostatni powołał się na znajomość z Żymierskim. Opowiadał, że pod koniec 1943 r. „Rola” osobiście zgłosił się do niego, ofiarując mu swoje usługi. Za sumę 500 tys. lub 50 tys. dolarów - Otto dokładnie tej sumy nie pamiętał przedstawił możliwość wydania przez niego gestapo całego kierownictwa Krajowej Rady Narodowej ${ }^{32}$. Wobec tego, że była to duża suma, jakiej warszawskie gestapo nie posiadało, zdecydowano się przekazać informację o tej propozycji do centrali w Berlinie. Brikner natomiast spotkał się z Żymierskim, przekazując mu 1500 albo 2000 dolarów, będących formą zaliczki. Według Briknera w tym też czasie został zlikwidowany przez gestapo działacz lewicowy o pseudonimie „Robert”, co łączył on z „wsypą”

${ }^{30}$ AIPN, 2386/14727, Akt oskarżenia przeciwko Staszauerowi vel Dalderowi Józefowi, 19 XI 1943, k. 6, 9.

${ }^{31}$ AIPN, 2386/14730, Protokół przesłuchania Stefana Rysia, 22 III 1954, k. 334-335 oraz AIPN, 2386/14726, Notatka sporządzona przez mjr. Zająca, 1 III 1954, k. 90.

${ }^{32}$ Krajowa Rada Narodowa powstała dopiero w nocy z 31 grudnia 1943 r. na 1 stycznia 1944 r., być może chodziło o kierownictwo PPR. 
dokonaną przez Żymierskiego. Do kolejnego spotkania jednak już nie doszło, a Brikner nie potrafił nawiązać ponownego kontaktu z „Rolą”. Słuchając tych opowieści, Spilker wyraził tylko żal z powodu niepowodzenia akcji ${ }^{33}$.Jednak już podczas kolejnego przesłuchania w lutym 1955 r. Otto odwołał zdecydowaną większość swoich zeznań dotyczących Żymierskiego. Według jego nowej wersji Brikner jedynie opowiadał mu o tym, że niejaki „Rola” oferował w początku 1944 r. chęć współpracy z gestapo, nie określał szczegółowo jej charakteru. Ostatecznie do żadnego współdziałania nie doszło, ponieważ „Rola” żądał za to zbyt dużo pieniędzy. Otto nie przypominał sobie bardziej szczegółowych swoich poprzednich zeznań, twierdząc, że od pół roku cierpi na zanik pamięci ${ }^{34}$.

Na podstawie powyższych dokumentów trudno jednoznacznie ustalić charakter kontaktów Żymierskiego z funkcjonariuszami i agentami niemieckiej tajnej policji. Jeśli Żymierski przyznawał się do nic nieznaczących kontaktów z Lewandowskim, to już konsekwentnie nie przyznawał się do rozmów z oficerami gestapo. Zeznawał także, że nigdy nie spotykał się ze Staszauerem, słyszał tyko o tym, że istniał „Bar za kotarą”, on sam nigdy w nim nie przebywał. Śledztwo prowadzone w latach pięćdziesiątych miało charakter polityczny, wątek ewentualnej współpracy Żymierskiego z gestapo był jednym z wielu, początkowo zresztą mniej ważnym dla zainteresowanych skazaniem komunistycznego dygnitarza. Natomiast pod koniec pobytu Żymierskiego w więzieniu, gdy ten trop próbowano wyjaśniać bardziej szczegółowo, nie było już czasu na rozwinięcie wszystkich wątków. Bez wątpienia Żymierski utrzymywał kontakty ze Staszauerem i przede wszystkim z Lewandowskim. Czy jednocześnie w sposób świadomy przekazywał także informacje niemieckim oficerom gestapo? W kwietniu 1955 r. oficer śledczy, ppłk Włodzimierz Gorzkowski, w raporcie na temat dotychczasowego przebiegu śledztwa w tej sprawie pisał o poszlakach, stwierdził nawet, że „przesłanki mogące świadczyć o tym, że Żymierski współpracował poprzez Lewandowskiego z gestapo, nie znalazły potwierdzenia i wyjaśnienia ich nie dały konkretniejszych rezultatów"35.

Latem 1955 r. śledztwo umorzono, a niemal rok później oczyszczono Żymierskiego ze wszystkich zarzutów. Czy był to tylko znak czasu, zmiana polityki na najwyższych szczeblach władzy? Powoli odstępowano przecież od stawianych komunistom zarzutów o spisek w łonie partii. Teraz ujawnienie oskarżeń wobec marszałka o współpracę z niemieckim wywiadem mogło

${ }^{33}$ AIPN, 2386/14731, Protokół przesłuchania Alfreda Otto, 6 IV 1954, k. 131-132.

${ }^{34}$ AIPN, 2386/14718, Notatka służbowa o wynikach śledztwa ws. Żymierskiego Michała, 21 III 1955, k. 274.

${ }^{35}$ AIPN, 2386/14718, Notatka służbowa o wynikach śledztwa ws. Żymierskiego Michała, 20 IV 1955, k. 345. 
stać się niewygodne i wstydliwe w oczach opinii publicznej. A może jednak faktycznie wiosną 1955 r. Bolesław Bierut, Jakub Berman, czy też Edward Ochab, a za nimi śledczy GZI uznali dotychczasowe ustalenia na temat agenturalnej działalności Żymierskiego dla niemieckiego wywiadu za pozbawione mocnych dowodów? Jeśli tak nawet było, to musiały one pozostawić cień na biografii Żymierskiego. Być może uznali oni tę aktywność za część jego działalności na rzecz sowieckiego wywiadu, z którym na stałe miał związać się ponownie wiosną 1942 r. Być może traktowali to jako podwójną grę, a korzyści z niej przypaść miały przede wszystkim wywiadowi sowieckiemu. Należy jednak pamiętać, że bliskie związki pomiędzy Żymierskim a Lewandowskim datowały się od końca 1939 r. do połowy 1942 r., a przecież wtedy jeszcze Żymierski kontaktów z wywiadem tym nie odnowił. Co w takim razie oznaczała jego znajomość z agentami gestapo? Może paradoksalnie w ten sposób chciał być w przyszłości, po nawiązaniu zerwanej w 1937 r. współpracy z sowieckimi służbami bardziej przydatny, może miał nadzieję, że dzięki kontaktom z gestapo Moskwa będzie jego osobą jeszcze bardziej zainteresowana. Pewne przesłanki mogły świadczyć o tym, że to właśnie przy pomocy Lewandowskiego, oczywiście bez jego wiedzy, Żymierski próbował wznowić łączność, przerwaną pod koniec lat trzydziestych.

Według zeznań Żymierskiego z lat pięćdziesiątych miał to zrobić na własną rękę, wbrew ostatnim dyrektywom wywiadowczym, które mówiły o oczekiwaniu na instrukcje z Moskwy. Jeszcze w maju lub w czerwcu 1940 r. poprosił Franciszka Czermanowicza, byłego członka Komunistycznej Partii Polski, którego poznał w czasie pobytu w więzieniu w latach trzydziestych, by w jego imieniu udał się do Lwowa. Żymierski przekonał Lewandowskiego, że wyjeżdżając, Czermanowicz będzie mógł uzyskać potrzebne dla niemieckiego wywiadu informacje $\mathrm{z}$ okupowanego przez Związek Sowiecki miasta. Dzięki Lewandowskiemu przepustkę taką wysłannik Żymierskiego otrzymał pod pretekstem wyjazdu do rodziny w Sanoku. Potem przekroczył granicę, dotarł do Lwowa, a stamtąd został przerzucony do Moskwy. W listopadzie 1940 r. Lewandowski poinformował Żymierskiego, że jego wysłannik podczas próby powrotu i przekraczania granicy został aresztowany i znajduje się w więzieniu w Sanoku. W areszcie Czermanowicz przebywał około trzech-czterech miesięcy, po czym Żymierski miał wyjednać przez Lewandowskiego jego zwolnienie. W końcu kurier wrócił do Warszawy i miał przekazać wiadomość z sowieckiej centrali, że Żymierski „ma siedzieć na miejscu, przesyłać informacje ${ }^{36}[!]$

${ }^{36}$ W wiadomości, którą miałby przekazać Czermanowicz Żymierskiemu, wątpliwość budzą choćby słowa o przesyłaniu informacji - Żymierski nie miał wówczas takich możliwości. 
i czekać na dalsze dyspozycje" 37 . Cała sprawa budzi wiele wątpliwości. Podstawowe pytanie brzmi, czy w ogóle Czermanowiczowi udało się dotrzeć do Moskwy i czy miał tam jakąkolwiek możliwość porozmawiania o pracy wywiadowczej Żymierskiego. Jest jedna wskazówka, która mogłaby potwierdzać, że tak naprawdę było. Otóż Adolf Matysiewicz, komunista, sowiecki agent, który w 1942 r. nawiązał kontakt z Żymierskim, jeszcze przed swoim wylotem ze Związku Sowieckiego do okupowanej Polski miał być pytany, czy zna Czermanowicza. Znaczyłoby to, że ten ostatni był znany sowieckim organom wywiadowczym ${ }^{38}$. W takim razie dlaczego wywiad sowiecki nie zdecydował się już wówczas nawiązać łączności z Żymierskim? Może nie był mu jeszcze potrzebny, może z uwagi na sojusznicze zobowiązania wobec III Rzeszy nie zależało mu na rozwijaniu siatki wywiadowczej. Być może też, jeśli nawet oficerowie sowieccy rozmawiali z Czermanowiczem, to mogli być nieufni wobec jego misji. W każdym razie według zeznań Żymierskiego miał on nie poprzestać tylko na tej jednej próbie i jeszcze raz, wiosną 1941 r., prosić Czermanowicza o wyjazd do Lwowa. Zeznawał w latach pięćdziesiątych: „Zbierałem materiały dla wywiadu radzieckiego [- - ]. Miałem wówczas szereg cennych wiadomości uzyskanych poprzez Związek Podoficerów Rezerwy. Widząc koncentrację wojsk niemieckich na Bugu, chciałem przyśpieszyć wyjazd Czermanowicza, ale z powodu jego choroby nie doszło to do skutku" ${ }^{\text {"39 }}$.

\section{Aktywność konspiracyjna}

Kontakty z agentami niemieckimi to tylko jedno z kilku pól aktywności Żymierskiego w czasie okupacji. Dla wielu polityków opozycyjnych wobec rządów sanacyjnych jego postać mogła być w pewien sposób interesująca. On sam przedstawiał siebie jako ofiarę Piłsudskiego, a proces z lat dwudziestych jako formę represji za opowiedzenie się po stronie rządowej w 1926 r. Na przełomie 1939 i 1940 r. starania o ściągnięcie Żymierskiego do Francji, gdzie działał rząd polski, prawdopodobnie czynił gen. Władysław Sikorski. Żymierski zeznawał w czasie pobytu w więzieniu w latach pięćdziesiątych: ,z końcem 1939 roku nawiązałem kontakt z Franciszkiem

${ }^{37}$ AIPN, 2386/14723, Uzupełnienie życiorysu, 18 XII 1949, k. 126. W tym dokumencie Żymierski podaje, jakoby chciał nawiązać kontakt ze swoimi dawnymi współtowarzyszami z KPP, jednak już podczas śledztwa mówił, że szukał wówczas kontaktu z wywiadem sowieckim. Patrz: AIPN, 2386/14715, Protokół przesłuchania Michała Żymierskiego, 26 II 1955, k. 57.

${ }^{38}$ AIPN, 2386/14714, Protokół przesłuchania Adolfa Matysiewicza, 23 II 1955, k. 131 oraz AIPN, 2386/14718, Notatka służbowa o wynikach śledztwa ws. Żymierskiego Michała, 21 III 1955, k. 274.

${ }^{39}$ AIPN, 2386/14715, Protokół przesłuchania Michała Żymierskiego, 26 II 1955, k. 57. 
Kwiecińskim z S[tronnictwa] P[racy], był on prawą ręką [Karola] Popiela ${ }^{40}$ na terenie Warszawy. [- - ] Kwieciński przekazał mi wiadomość, że bracia Stanisław i Józef dotarli do Paryża i że Sikorski wzywa mnie tam również"41. W stolicy Francji faktycznie znaleźli się Józef i Stanisław Żymierscy.Jeszcze pod koniec grudnia zostali oni wysłani jako kurierzy rządu polskiego do okupowanego kraju. Prawdopodobnie jednym z głównych ich zadań było nawiązanie kontaktu z bratem i próba ściągnięcia go do Paryża. Obaj zostali jednak aresztowani na granicy sowiecko-rumuńskiej i trafili do więzienia w Moskwie ${ }^{42}$. Potwierdzeniem tych słów są też zeznania z lat pięćdziesiątych Wincentego Bryi ${ }^{43}$, członka przedwojennego i okupacyjnego Stronnictwa Ludowego. Miał on spotkać Żymierskiego w styczniu 1940 r. w mieszkaniu Franciszka i Leokadii Sarnaków ${ }^{44}$. Wówczas Żymierski miał mówić o rozmowach prowadzonych przez niego z Ryszardem Świętochowskim. Ten ostatni był przedwojennym członkiem Frontu Morges oraz SL, a w czasie okupacji stanął na czele Centralnego Komitetu Organizacji Niepodległościowych, który nie chciał podporządkować się ZWZ, za to popierał rząd Sikorskiego ${ }^{45}$. Świętochowski reprezentował Sikorskiego i Żymierski chwalił

${ }^{40}$ Karol Popiel (1887-1977) - w czasie I wojny światowej walczył w Legionach, w latach trzydziestych członek Frontu Morges, prezes SP, w czasie okupacji minister w rządzie gen. Sikorskiego. Żymierski znał Popiela jeszcze z czasów wspólnej pracy w Polskich Drużynach Strzeleckich przed 1914 r.

${ }^{41}$ AIPN, 2386/14715, Protokół przesłuchania Michała Żymierskiego, 25 II 1955.

${ }^{42}$ S. Żymierski podczas śledztwa w 1954 roku zeznawał, że na temat ściągnięcia do Paryża Michała Żymierskiego rozmawiał z gen. Izydorem Modelskim, który wówczas był drugim zastępcą ministra spraw wojskowych, czyli gen. Sikorskiego, i m.in. odpowiadał za sprawy personalne w armii, zajmował się ewakuacją wyższych oficerów internowanych w różnych krajach Europy do Francji. Według zeznań Stanisława Żymierskiego Modelski mówił, że przybyciem Michała do Paryża zainteresowany był zarówno gen. Sikorski, jak i sam gen. Maurice Gamelin, naczelny wódz armii francuskiej. Archiwum Służby Sprawiedliwości MON, 161/91, t. 1447, Protokół przesłuchania Stanisława Żymierskiego, 3 VI 1954, k. 95. O aresztowaniu Żymierskich czytaj: Polskie podziemie 1939-1941. Polska i Ukraina w latach trzydziestych-czterdziestych XX wieku. Nieznane dokumenty z archiwum służb specjalnych. Lwów-Kołomyja-Stryj-Złoczów, t. 1, red. Z. Gajowniczek i in., Warszawa-Kijów 1998, s. 715.

${ }^{43}$ Wincenty Bryja (1897-1973) - w latach 1942-1945 kierownik sekcji finansowo-budżetowej Biura Prezydialnego Delegatury Rządu RP na Kraj. Po wojnie skarbnik Polskiego Stronnictwa Ludowego, poseł do KRN, następnie od 1947 r. na Sejm Ustawodawczy. Zagrożony aresztowaniem, podjął w 1947 r. próbę ucieczki z kraju, zatrzymany, więziony do $1954 \mathrm{r}$.

${ }^{44}$ Franciszek Sarnak był gimnazjalnym kolegą Żymierskiego, w wyniku kampanii 1939 r. został internowany w Rumunii. Leokadia Sarnak sympatyzowała z SL, należała też do Związku Walki Zbrojnej.

${ }^{45}$ Ryszard Świętochowski wyruszył 23 kwietnia 1940 r. z misją do gen. Sikorskiego do Paryża, został aresztowany na Słowacji i uwięziony, zginął w obozie koncentracyjnym Auschwitz. Patrz: A. K. Kunert, Ilustrowany przewodnik po Polsce Podziemnej 19391945, Warszawa 1996, s. 590. 
się Bryi, że dostał od niego „osobiste pismo gen. Sikorskiego zalecające Żymierskiemu wciągnięcie się w szeregi ZWZ"46.

Ostatecznie przyszły marszałek nie zdecydował się na wyjazd do Paryża. Oczywiście pozostaje wątpliwość, czy w ogóle miał takie możliwości. Sam zeznawał, że stało się to z powodu niewiary w gen. Sikorskiego i w zwycięstwo Francji nad Niemcami. Natomiast rozpoczął starania o włączenie się w działalność konspiracyjną w kraju. Zdawał sobie sprawę z tego, że ograniczał go w tej aktywności sądowy wyrok z 1927 r. Zapewne pod wpływem rozmów przeprowadzonych z politykami konspiracyjnymi doszedł do wniosku, że należy w jakiś sposób zminimalizować jego wydźwięk i postanowił zorganizować tzw. sąd obywatelski. Na przełomie 1939 i 1940 r. zaczął czynić starania, aby zgromadzić wokół siebie polityków, którzy mogliby w nim zasiadać i zgodziliby się przeprowadzić odpowiednie postępowanie. Podczas jednego ze spotkań u L. Sarnak Żymierski zwrócił się do Bryi o pomoc w „osobistej sprawie”. Zaproponował mu zasiadanie w takim gremium. Obok niego znaleźli się w nim:jako przewodniczący inny działacz SL, były senator, inżynier, przyjaciel Żymierskiego z lat dwudziestych Wacław Januszewski ${ }^{47}$, a także Tadeusz Garczyński ${ }^{48}$, Józef Szwajcer ${ }^{49}$ i Marian Borzęcki ${ }^{50}$.Członkami gremium orzekającego byli politycy niższego szczebla, przede wszystkim ludzie związani z ruchem ludowym, a także przeciwnicy rządów przedwrześniowych. Tak zwany sąd spotykał się kilka razy w miesz-

${ }^{46}$ BO, rkp. 15347/II/2, W. Bryja, „O jedność wsi. Zrzeszenie Inteligencji Ludowej 1936-1939", s. 95, 105.

${ }^{47}$ Wacław Januszewski (1880-1953) - członek POW; w 1917 r. członek Tymczasowej Rady Stanu, wiceminister spraw wewnętrznych w 1918 r.; działał w PSL „Wyzwolenie”, m.in. członek Zarządu Głównego i Głównej Komisji Rewizyjnej; w latach 19211922 szef działu przemysłu wojennego w Ministerstwie Spraw Wojskowych; współtwórca i członek zarządu Ligi Obrony Powietrznej i Przeciwgazowej; prezes Instytutu Aerodynamicznego; senator trzech kadencji. W czasie okupacji członek konspiracyjnego Stronnictwa Ludowego „Roch”; od 1942 r. zastępca dyrektora Departamentu Spraw Wewnętrznych Delegatury Rządu RP na Kraj, a od 1944 prezes konspiracyjnej Najwyższej Izby Kontroli. Po wojnie członek Głównego Sądu Partyjnego PSL, a od 1949 r. członek Zjednoczonego Stronnictwa Ludowego.

${ }^{48}$ Były przewodniczący Związku Dziennikarzy i Publicystów Gospodarczych, po wojnie w PSL, redaktor „Gazety Ludowej”.

${ }^{49}$ Były Komendant Główny Straży Obywatelskiej Rzeczypospolitej, prezes Rady Miejskiej w Warszawie.

${ }^{50}$ Marian Borzęcki (1889-1942) - m.in. w latach 1922-1923 dyrektor Departamentu Bezpieczeństwa w Ministerstwie Spraw Wewnętrznych, potem do 1926 r. komendant główny Policji Państwowej. Zwolniony z funkcji po przewrocie majowym. Działacz Stronnictwa Narodowego, od 1937 r. członek SP. W latach 1927-1934 wiceprezydent Warszawy. We wrześniu 1939 r. członek Komitetu Obywatelskiego przy Dowództwie Obrony Warszawy. W konspiracji w Biurze Politycznym Centralnego Komitetu Organizacji Niepodległościowych, aresztowany w marcu 1940 r., zamordowany w obozie w Mauthausen. 
kaniu Januszewskiego ${ }^{51}$.W ostatnich dwóch naradach uczestniczył Żymierski. Wreszcie 22 lutego 1940 r. „sąd” wydał orzeczenie, w którym ,po wysłuchaniu sentencji wyroku Sądu Wojskowego z września 1927 roku oraz po wysłuchaniu wyczerpujących wyjaśnień generała Michała Żymierskiego wobec znanego Sądowi Obywatelskiemu politycznego nastawienia Sądu Wojskowego w czasie procesu gen. Żymierskiego" stwierdzał, że zawiesza skutki prawne wynikające $\mathrm{z}$ wyroku Żymierskiego. Zapisano w nim ponadto, iż „w chwili powrotu do normalnych warunków”, czyli po odbudowie państwa polskiego, należało przeprowadzić proces rewizyjny, a do tego czasu Żymierski „nie powinien napotkać w działalności swej obywatelskiej na żadne przeszkody, ani na żadne zarzuty z treści cytowanego wyroku wynikające" 52 .Zbyteczne dodawać, że grono orzekające, polityczni stronnicy Żymierskiego, nie miało żadnych podstaw prawnych do „,weryfikowania”, budowania wątpliwości wokół wyroku niezawisłego sądu.

Żymierski szybko włączył się do działań konspiracyjnych, ale początkowo nie w głównym ich nurcie. Wiosną 1940 r. kontakt z Żymierskim nawiązał Antoni Jakubowski ${ }^{33}$, przed wojną prezes Związku Podoficerów Rezerwy, który teraz zdecydował się kontynuować działalność w konspiracji. Była to mało znacząca organizacja na mapie polskiej konspiracji, jedna z wielu, które pojawiły się tuż po nastaniu niemieckiej okupacji w Warszawie. Jak zeznawał Jakubowski, ,związek ten w zasadzie szczególnego kierunku politycznego nie miał", chociaż stał na stanowisku podporządkowania się rządowi na wychodźstwie. Żymierski natomiast stwierdzał podczas przesłuchania, że organizacja nie uznawała „rządu Sikorskiego i przeciwstawiała się dowództwu ZWZ-AK" "54. Jakubowski zaproponował Żymierskiemu podjęcie pracy na stanowisku komendanta, ten się zgodził ${ }^{55}$. Jednocześnie Jakubowski wraz z Żymierskim oraz Wincentym Makowskim i Mieczysławem Pietraszkiem ${ }^{56}$ założyli organizację pod nazwą Komitety

${ }^{51}$ AIPN, 2386/14730, Protokół przesłuchania Wincentego Bryi, 6 III 1954, k. 325-326.

${ }_{52}$ AIPN, 2386/14727, Odpis orzeczenia sądu obywatelskiego, 22 II 1940, k. 58.

${ }^{53}$ Antoni Jakubowski (1887-1960) - od 1929 r. pełnił funkcję prezesa Zarządu Głównego Związku Podoficerów Rezerwy RP. Po wojnie poseł KRN, w latach pięćdziesiątych aresztowany przez MBP.

${ }^{54}$ AIPN, 2386/14715, Protokół przesłuchania Michała Żymierskiego, 26 III 1955, k. 58.

${ }_{55}$ AIPN, 2386/14730, Protokół przesłuchania Antoniego Jakubowskiego, 4 III 1955, k. 149.

${ }^{56}$ Wincenty Makowski - żołnierz Legionów Polskich, w okresie międzywojennym szef wydziału w Urzędzie Wojewódzkim Warszawskim, podczas okupacji prowadził działalność konspiracyjną w polskich organizacjach niepodległościowych. Brat Franciszka Makowskiego, w latach trzydziestych wysokiego oficera sowieckiego wywiadu wojskowego (GRU), który wówczas ,prowadził” Żymierskiego.

Mieczysław Pietraszek (1889-1961) - od 1923 r. w Zarządzie Głównym Ligi Obrony Przeciwpowietrznej Państwa, potem m.in. wykładał na Politechnice Warszawskiej, 
Wolności. Miała to być organizacja o charakterze charytatywnym, przynajmniej tak ją przedstawiał Jakubowski, a nie politycznym ${ }^{57}$. W $1942 \mathrm{r}$. w ramach tej działalności Żymierski wraz z Jakubowskim i Pietraszkiem udali się do Krakowa, by tam rozmawiać z prezesem Rady Głównej Opiekuńczej Adamem Ronikierem oraz wspomagającym jej działalność kardynałem Adamem Stefanem Sapiehą ${ }^{58}$. Podczas tego spotkania Żymierski wraz z Jakubowskim przekonywali kierownictwo RGO do udzielenia poparcia finansowego dla Komitetów Wolności, mieli także mówić o nieuchronnym zwycięstwie Związku Sowieckiego (już w 1942 r.!). Żymierski dodawał podczas zeznań, że przekonywał Ronikiera i Sapiehę, aby w oparciu o organizację budować przyszłą władzę, a w momencie wkraczania na tereny polskie Armii Czerwonej, poprzez właśnie Komitety Wolności prowadzić rozmowy z przedstawicielami Związku Sowieckiego ${ }^{59}$. Jakubowski nie potwierdzał tych informacji. Ostatecznie przedstawiciele RGO mieli przyjąć „pozycję wyczekującą, jedynie pomóc osobom wskazanym przez Jakubowskiego poprzez przekazanie im zapomóg finansowych ${ }^{60}$. Inaczej o kontaktach Żymierskiego z Sapiehą zeznawał natomiast Pietraszek. Podczas spotkań konspiracyjnych mieli rozmawiać o połączeniu różnych organizacji zbrojnych, które nie podporządkowały się AK, w celu stworzenia jednolitego ich kierownictwa. O tym też mieli dyskutować z Sapiehą ${ }^{61}$. Podobnie o charakterze kilkukrotnych kontaktów Żymierskiego i Jakubowskiego z kierownictwem RGO zeznawał Paweł Piskozub ${ }^{62}$, wówczas członek Komitetów Wolności oraz Związku Podoficerów Rezerwy. Według niego, jeszcze w 1942 r. mieli oni wspólnie zastanawiać się nad powołaniem nowego ośrodka politycznego i wojskowego organizacji niepodporządkowujących się Delegaturze Rządu na Kraj i AK oraz namawiać Sapiehę do

w 1939 r. w stopniu pułkownika. W 1945 r. dyrektor Departamentu Lotnictwa Cywilnego Ministerstwa Komunikacji.

${ }^{57}$ AIPN, 2386/14730, Protokół przesłuchania Antoniego Jakubowskiego, 4 III 1955, k. 149.

${ }^{58}$ Ibidem.

${ }^{59}$ AIPN, 2386/14715, Protokół przesłuchania Michała Żymierskiego, 26 III 1955, k. 58.

${ }^{60}$ AIPN, 2386/14718, Notatka służbowa o wynikach śledztwa ws. Żymierskiego Michała, 21 III 1955, k. 276-277.

${ }^{61}$ AIPN, 2386/14715, Protokół przesłuchania Mieczysława Pietraszka, 31 III 1955, k. 72-73.

${ }^{62}$ Paweł Piskozub przed II wojną w Wojsku Polskim w stopniu majora, w latach trzydziestych był m.in. pracownikiem Biura Wojskowego Dyrekcji Poczt i Telegrafów. W czasie okupacji należał do Komitetów Wolności oraz Związku Podoficerów Rezerwy oraz Wojskowego Korpusu Służby Bezpieczeństwa oraz Miecza i Pługa. Po wojnie w ludowym Wojsku Polskim, w latach 1945-1946 zastępca dowódcy dywizji szkolnej. W latach pięćdziesiątych aresztowany, skazany na 10 lat więzienia, zrehabilitowany w $1958 \mathrm{r}$. 
wsparcia tych poczynań. W celu rozszerzenia wpływów nowo powstającego ośrodka konspiracyjnego próbowano wciągnąć do tych działań także organizację Miecz i Pług. Żymierski i Jakubowski zaprzeczali informacjom mówiącym o próbach utworzenia jakiejś organizacji o szerszym zasięgu, natomiast potwierdzali fakt nawiązania kontaktów z Mieczem i Pługiem.

Miecz i Pług był organizacją utworzoną jeszcze w 1939 r. przez działaczy chrześcijańsko-narodowych o dosyć dużym zasięgu konspiracyjnym, jednocześnie niepodporządkowująca się strukturom ZWZ/AK ${ }^{63}$. Po aresztowaniu przez Niemców pierwszego kierownictwa Miecza i Pługa na jego czele stanęli Anatol Słowikowski i Zbigniew Grad, oficerowie przedwojennego II Oddziału Sztabu Głównego. Jeszcze w 1942 r. Jakubowski miał namówić Żymierskiego do podjęcia rozmów z przedstawicielami tej organizacji. Żymierski zeznawał, że prowadził je na początku $1943 \mathrm{r}$. W tym czasie trzykrotnie spotkał się ze Słowikowskim i Gradem. Podczas ostatniego spotkania Grad miał zakomunikować Jakubowskiemu i Żymierskie$\mathrm{mu}$, że ten ostatni został mianowany przez kierujących Mieczem i Pługiem jego wojskowym komendantem. Żymierski miał być zdenerwowany takim postawieniem sprawy - nominacją, którą otrzymał bez konsultowania się z nim. Zerwał wszelkie kontakty z Gradem i Słowikowskim. Jednocześnie Żymierski zeznawał, że nic nie wiedział o wysuwanych wobec nich oskarżeniach o współpracę z gestapo. Tymczasem Słowikowski i Grad, którzy starali się rozszerzać zasięg oddziaływania swej organizacji, utrzymywali także kontakty z niemiecką tajną policją bez informowania o tym swoich współpracowników. W polskich strukturach podziemnych panowała opinia, że są niemiecką agenturą. Wobec tego w centrali Miecza i Pługa zdecydowano się przeprowadzić zamach ${ }^{64}$. Dnia 18 września 1943 r. obaj zostali zastrzeleni przez pluton specjalny AK, a o całej akcji zameldowano przedstawicielowi Delegatury Rządu na Kraj ${ }^{65}$. Natomiast rozmowy dotyczące utworzenia nowego ośrodka politycznego, początkowo bez Miecza i Pługa, zostały uwieńczone powołaniem w listopadzie 1943 r. Rady Obrony Narodu. Na jej czele stanął Antonii Karczewski ${ }^{66}$,

${ }^{63}$ B. Chrzanowski, Miecz i Pług (Zjednoczone organizacje ruchu „Miecz i Pług”) na Pomorzu w latach okupacji niemieckiej 1939-1945, Toruń 1997.

${ }^{64}$ Jednym z inspiratorów zamachu był Hrynkiewicz, także znajdujący się w kierownictwie organizacji. Sprawę dodatkowo komplikuje fakt, że był on sowieckim agentem. Nierozwiane pozostają wątpliwości co do tego, czy aby inspiracja do zamachu nie przyszła z Moskwy.

${ }^{65}$ B. Chrzanowski, op. cit., s. 67-68.

${ }^{66}$ W latach trzydziestych XX w. był konserwatorem zabytków m.st. Warszawy. W czasie okupacji zaangażował się w działalność Centralnego Komitetu Organizacji Niepodległościowych kierowanego przez Świętochowskiego, po wojnie był profesorem Politechniki Krakowskiej. 
a także Jakubowski. W swoich początkowych założeniach miał być to ośrodek skupiający prawicowe ugrupowania, faktycznie jednak była to organizacja o bardzo ograniczonym zasięgu politycznym, która stała się tak naprawdę „nadbudówką” polityczną organizacji zbrojnej Korpus Bezpieczeństwa, dowodzonej przez płk. Andrzeja Petrykowskiego „Tarnawę". Kierownictwo organizacji Miecz i Pług wstąpiło do RON już po powstaniu warszawskim. Zarówno Piskozub, jak i Pietraszek zeznawali, że Żymierski został członkiem RON ${ }^{67}$. Potwierdzenie tego miało znajdować się także w zeznaniach Bogusława Hrynkiewicza i Władysława Byszka. Należy jednak zaznaczyć, że w 1955 r. Piskozub większość swoich zeznań dotyczących rozmów Żymierskiego z kierownictwem RGO oraz przynależnością tego ostatniego do RON odwołał, a Hrynkiewicz i Byszek mieli tylko słyszeć o takiej działalności ${ }^{68}$. Żymierski natomiast nie przyznawał się do przynależności do RON ${ }^{69}$.

Według kolejnych zeznań z okresu pobytu Żymierskiego w więzieniu w latach pięćdziesiątych, próbował on nawiązać kontakt z byłym premierem Leonem Kozłowskim. Czynił to poprzez jego rodzinę ${ }^{70}$. Poszukiwania takie były prawdopodobne, ale samo spotkanie niemal niemożliwe, ponieważ Kozłowski po przekroczeniu frontu niemiecko-sowieckiego w 1941 r. aż do śmierci (w 1944 r.) przebywał w Berlinie. Znowu inne źródła mówiły o tym, że na początku okupacji Żymierski próbował wstąpić do Narodowych Sił Zbrojnych. W swoich wspomnieniach wydanych po wojnie w Londynie wzmiankował o tym Zbigniew Stypułkowski ${ }^{71}$, m.in. członek Wojennego Zarządu Głównego Stronnictwa Narodowego i sekretarz Tymczasowej Narodowej Rady Politycznej. Bardzo trudno zweryfikować te informacje, jednak w materiałach śledczych z lat pięćdziesią-

${ }^{67}$ AIPN, 2386/14715, Protokół przesłuchania Mieczysława Pietraszka, 31 III 1955, k. 72-73.

${ }^{68}$ AIPN, 2386/14718, Notatka służbowa o wynikach śledztwa ws. Żymierskiego Michała, 21 III 1955, k. 278.

${ }^{69}$ AIPN, 2386/14730, Protokół przesłuchania Pawła Piskozuba, 14 XI 1950, k. 254 oraz AIPN, 2386/14715, Protokół przesłuchania Pawła Piskozuba, 7 IV 1955, k. 56-57.

70 Zeznawać o tym miał więziony przez MBP Henryk Borucki, w czasie okupacji najpierw komendant konspiracyjnej Komendy Obrońców Polski, potem po aresztowaniu i zwolnieniu przez gestapo dowódca podziemnej Polskiej Armii Ludowej, jednocześnie agent tajnej niemieckiej policji. AIPN, 2386/14718, Notatka służbowa o wynikach śledztwa ws. Żymierskiego Michała, 21 III 1955, k. 278.

${ }^{71}$ Pisał on dosyć sarkastycznie: „Nie przyjęto więc Żymierskiego w NSZ. W zasadzie dobrze, no bo któż byłby dowódcą AL i potem Wojska Polskiego". Patrz: Z. Stypułkowski, W zawierusze dziejowej. Wspomnienia 1939-1945, Londyn 1951. Słowa te zostały potem powtórzone w monografii Narodowych Sił Zbrojnych w następującym brzmieniu: „Do NSZ zgłosił się również po przybyciu z Francji zdegradowany przed wojną [- - ] były generał Michał Żymierski, późniejszy dowódca Armii Ludowej, ale nie został przyjęty”. Z. Siemaszko, Narodowe Siły Zbrojne, Londyn 1982 (reprint Gdańsk 1989), s. 38. 
tych zarzut mówiący o próbie nawiązania współpracy z tą ostatnią organizacją nie był wysuwany przez oficerów GZI. Natomiast jednym z głównych wątków badanych przez śledczych w latach pięćdziesiątych były kontakty Żymierskiego z ZWZ/AK.

Żymierski wielokrotnie podejmował próby wstąpienia do tej organizacji. W swoich zeznaniach uzasadniał próby nawiązania kontaktu z ZWZ/AK chęcią odzyskania stopnia generalskiego, czy też po prostu „wstąpienia do AK”, ale mówił także o tym, że „chciał uzyskać wpływ na Roweckiego oraz możliwości zdobywania materiałów dla wywiadu radzieckiego"72.

Prawdopodobnie po raz pierwszy Żymierski w tej sprawie zwracał się na początku 1940 r. do majora Antoniego Sanojcy, szefa I Oddziału (Organizacyjnego) ZWZ. Przyjęcie do organizacji miało być uzależnione od przeprowadzenia przez tzw. sąd obywatelski rehabilitacji Żymierskiego oraz od wyniku konsultacji z przedstawicielami dowództwa WP na Zachodzie ${ }^{73}$. Niejako potwierdzeniem tego były rozmowy, jakie prowadził Żymierski z Bryją na wiosnę 1940 r., niedługo po wydaniu oświadczenia sądu obywatelskiego. Żymierski wiedział, że Bryja posiada kontakty z konspiracyjnym kierownictwem SL, i wobec tego prosił go, by ten ,załatwił sprawę jego przyjęcia do ZWZ". Bryja zwrócił się do Józefa Grudzińskiego, przedstawiciela ludowców w Politycznym Komitecie Porozumiewawczym, a potem w Krajowej Reprezentacji Politycznej. Po pewnym czasie Grudziński miał odpowiedzieć, że nie zgodzono się na przyjęcie Żymierskiego ${ }^{74}$. Bryja zeznawał: „Powiadomiłem go o tym i czuł on się tym dotknięty”. Żymierski ponowił swoją prośbę w końcu $1941 \mathrm{r}$. Tym razem przyszły komunistyczny marszałek uważał, że gen. Stefan Rowecki „Grot” przyjmie ją pozytywnie, ponieważ jest „doświadczonym oficerem i [Żymierski - J.P.] uznawał go za lewicującego". Bryja ponownie rozmawiał o tym z Grudzińskim i ponownie prośbie byłego wojskowego odmówiono. Ludowiec miał rzec, że wejściu Żymierskiego do ZWZ stanowczo sprzeciwił się płk Tadeusz Pełczyński, w tym czasie szef sztabu Komendy Głównej AK.Pełczyński przed wojną był szefem

72 AIPN, 2386/14718, Notatka służbowa o wynikach śledztwa ws. Żymierskiego Michała, 21 III 1955, k. 275.

${ }^{73} \mathrm{O}$ takim warunku zeznawał Kazimierz Pluta-Czachowski, w czasie okupacji szef V Oddziału (Łączności) i zasteppca szefa sztabu KG AK. Patrz: AIPN, 2386/14718, Notatka służbowa o wynikach śledztwa ws. Żymierskiego Michała, 21 III 1955, k. 276.

${ }^{74} \mathrm{O}$ podobnym epizodzie, który miał jednak miejsce nieco później, wspominał także Stefan Korboński, działacz ludowy, który był w czasie okupacji członkiem Politycznego Komitetu Porozumiewawczego, a potem szefem Kierownictwa Walki Cywilnej przy Delegaturze Rządu na Kraj. „Przyjaciel” z SL miał mu zaproponować spotkanie z Żymierskim, który chciał się przyłączyć do „naszego podziemia”. Korboński przy okazji dowiedział się o „oczyszczeniu” Żymierskiego przez tzw. sąd obywatelski, jednak propozycji spotkania nie przyjął. Patrz: S. Korboński, W imieniu Rzeczypospolitej..., Warszawa 2009, s. 276. 
II Oddziału (wywiadowczego) Sztabu Głównego i mógł mieć pewne informacje o niejasnych działaniach Żymierskiego podczas jego pobytu w Paryżu w latach trzydziestych. Teraz miał grozić odsunięciem się od pracy w organizacji, w przypadku przyjęcia Żymierskiego. Ten zaś, dowiedziawszy się o odmowie, zarzucał Bryi, że załatwiał tę sprawę bez „należytej energii”. Po raz ostatni Żymierski zwrócił się do Bryi w 1943 r. z propozycją przyjęcia go do Batalionów Chłopskich. Bryja po rozmowach z dowódcą BCh ppłk. Franciszkiem Kamińskim znów musiał przekazać Żymierskiemu negatywną odpowiedź. Kamiński miał uzasadniać odmowę tym, że organizacja była wówczas w trakcie rozmów scaleniowych z AK i przyjęcie Żymierskiego do BCh utrudniałoby takie działania ${ }^{75}$.Żymierski w nieco innym świetle przedstawiał swoje kontakty z Bryją. Nie potwierdzał tego, że kiedykolwiek wysuwał wobec niego prośby o pomoc w nawiązaniu kontaktu z AK, potwierdzał natomiast zabiegi o wstąpienie do BCh, w 1941 bądź w 1942 r., aby - oczywiście - „zapobiec zbliżeniu się organizacji chłopskiej do AK"76.

Pomimo tych niepowodzeń Żymierski nie zaprzestał prób związania się z ZWZ. Niedługo potem miał mu pomagać Jakubowski, który kontaktował się z mjr. Ludwikiem Muzyczką, wówczas stojącym na czele administracji wojskowej, tzw. Biur Wojskowych w Komendzie Głównej ZWZ-AK. W latach pięćdziesiątych zeznania Muzyczki i Żymierskiego wykluczały się. Wobec tego oficerowie śledczy postanowili w kwietniu 1955 r. przeprowadzić pomiędzy nimi konfrontację ${ }^{77}$. Podczas niej komunistyczny marszałek zeznał, że widział się z Muzyczką tylko raz, wspólnie z Jakubowskim. Spotkanie miało dotyczyć ewentualnych dotacji skierowanych przez ZWZ dla Związku Podoficerów Rezerwy, ponadto Żymierski prosił o możliwość spotkania się z Grotem-Roweckim. Zeznania Muzyczki były dużo bardziej rozbudowane. Obaj mieli spotkać się w czasie okupacji kilkakrotnie, po raz pierwszy w 1941 r.,Żymierski prosił o możliwość wstąpienia do ZWZ. Muzyczka miał sprawę przedstawić Grotowi-Roweckiemu. Odpowiedź od dowódcy ZWZ przyszła na początku 1942 r. Zgodnie z zeznaniami Muzyczki Grot-Rowecki zgodził się na wstąpienie Żymierskiego do ZWZ, z zastrzeżeniem, aby nie przydzielać mu pracy w Komendzie Głównej, ale w administracji wojskowej na niskim szczeblu. Podczas następnego spotkania w mieszkaniu notariusza Jana Knacha, także członka Związku Podoficerów Rezerwy, Żymier-

${ }^{75}$ AIPN, 2386/14731, Protokół przesłuchania Wincentego Bryi, 6 III 1954, k. 95-96.

${ }^{76}$ AIPN, 2386/14718, Notatka służbowa o wynikach śledztwa ws. Żymierskiego Michała, 21 III 1955, k. 276.

${ }^{77}$ Muzyczka w tym czasie przebywał już na wolności. Aresztowany został najpierw w 1945 r., zwolniony w 1948, a potem ponownie w 1950 r. i zwolniony z więzienia 3 maja 1954 r. Patrz: A. K. Kunert, Słownik biograficzny konspiracji warszawskiej 19391944, t. 2, Warszawa 1987, s. 134-135. 
ski miał złożyć przysięgę „obowiązującą osobę przystępującą do AK”. Sam zainteresowany przyznawał się do tego, że złożył przysięgę przed Muzyczką, ale miała ona dotyczyć tylko spotkania: „na utrzymanie w tajemnicy miejsca i osób biorących w nim udział". Sam przyznał, że był zdziwiony taką przysięgą i po raz pierwszy w swojej działalności konspiracyjnej spotkał się z takim jej rodzajem ${ }^{78}$. Natomiast dalsze zeznania Muzyczki brzmiały następująco:

Miałem trudności ze skierowaniem Żymierskiego na odpowiednią pracę, a nadto z uwagi, iż zachodziła konieczność przeprowadzenia wywiadu odnośnie charakteru organizacji, do jakiej Żymierski uprzednio należał, a z którą chciał wejść do AK, sprawa skierowania Żymierskiego przeciągała się do końca 1942 roku. [- - ] W końcu 1942 roku sprawując zwierzchnictwo nad KB [Korpus Bezpieczeństwa, potem Wojskowy Korpus Służby Bezpieczeństwa - J.P.] z ramienia AK, zdecydowałem skierować Żymierskiego na stanowisko doradcy komendanta głównego „Tarnawy” Petrykowskiego. Wówczas skontaktowałem tego ostatniego z Żymierskim i od tego czasu do końca 1943 roku pozostawał na tym stanowisku.

W tym okresie spotkania ich miały odbywać się regularnie, uczestniczyć miał w nich także Petrykowski. Kontakt Muzyczki z Żymierskim urwał się w grudniu 1943 r. ${ }^{79}$ Te zeznania stają w sprzeczności z zeznaniami Żymierskiego, ale też Bryi. Natomiast Petrykowski zeznawał, że nigdy podczas okupacji nie spotkał Żymierskiego.Jednak na początku 1944 r. za namową Leona Bąkowskiego ps. Rawicz, szefa sztabu Oddziałów Wojskowych Korpusu Bezpieczeństwa, miał mianować Żymierskiego swoim zastępcą w Wojskowym Korpusie Służby Bezpieczeństwa, organizacji personalnie powiązanej z OW KB. Ostatecznie jednak Żymierski nie pojawił się w umówionym wcześniej miejscu i nie doszło do objęcia przez niego stanowiska w WKSB ${ }^{80}$. W ten sposób zeznania Petrykowskiego także podważały wersję Muzyczki. Jedynie Jakubowski oraz Knach potwierdzali fakt spotkania Muzyczki z Żymierskim w mieszkaniu Knacha, z tym, że zaprzeczali, jakoby Żymierski miał na nim zostać zaprzysiężony do służby w $\mathrm{AK}^{81}$.

Wydaje się, że nawet jeśli formalnie Grot-Rowecki zgodził się na włączenie Żymierskiego w struktury AK, to praktycznie nie pełnił on w nich

${ }^{78}$ AIPN, 2386/14715, Protokół przesłuchania Michała Żymierskiego, 26 III 1955, k. 54.

${ }^{79}$ AIPN, 2386/14715, Protokół konfrontacji pomiędzy świadkiem Ludwikiem Muzyczką a podejrzanym Michałem Żymierskim, 13 IV 1955, k. 62-68.

${ }^{80}$ AIPN, 2386/14715, Protokół przesłuchania Andrzeja Petrykowskiego, 8 IV 1955, k. 57-58.

${ }^{81}$ AIPN, 2386/14728, Protokół przesłuchania Jana Knacha, 5 I 1955, k. 285. 
żadnych funkcji. Propozycja wysunięta przez Muzyczkę, w imieniu dowództwa organizacji, skierowania go do prac konspiracyjnym na niskim szczeblu, nie mogła zadowolić aspiracji wówczas już stałego agenta sowieckiego wywiadu, związanego bardzo mocno z komunistyczną partyzantką.

\section{Dowódca komunistycznej partyzantki}

Decydujący moment dla Żymierskiego przyszedł wiosną 1942 r. Wówczas do Warszawy dotarli dwaj agenci sowieckiego wywiadu - Józef Małecki „Sęk" i A. Matysiewicz. Nocą z 24 na 25 marca zostali oni przerzuceni samolotem ze Związku Sowieckiego ${ }^{82}$ na teren okupowanego przez Niemców kraju.Jak wspominał Małecki: „Celem naszym z góry ustalonym była Warszawa, w której zarówno ja, jak i towarzysz Matysiewicz przed wojną mieszkaliśmy i pracowaliśmy. Stąd też liczyliśmy na szerokie nasze znajomości ułatwiające naszą działalność"83. Jednym z zadań Matysiewicza, które otrzymał w Moskwie - wydaje się nawet, że zadaniem głównym - miało być ponowne nawiązanie kontaktu z dawnym agentem, Żymierskim. Dla uwiarygodnienia swojej osoby Matysiewicz otrzymał w Moskwie list pisany przez brata Michała, Stanisława ${ }^{84}$. Dostał także adres narzeczonej

82 Obok dwóch wywiadowców zrzucony wówczas został także radiotelegrafista Stanisław Jezierski.

${ }^{83}$ AAN, Zbiór akt osobowych działaczy ruchu robotniczego, 3787, Józef Małecki „Sęk”, Wspomnienia, t. 1, k. 92. W 1962 r. opublikowane zostały wspomnienia J. Sęka-Małeckiego Armia Ludowa w Powstaniu Warszawskim. Wspomnienia (Warszawa 1962), nie znalazły się jednak w nich fragmenty tu publikowane.

${ }^{84}$ Stanisław i Józef Żymierski, bracia Michała, zostali sowieckimi agentami w latach trzydziestych w wyniku pracy tego ostatniego dla NKWD. W czasie kampanii 1939 r., po ewakuacji, obaj znaleźli się w Paryżu, gdzie zostali zaprzysiężeni do ZWZ. W styczniu 1940 r. jako emisariusze ZWZ z Paryża próbowali przedostać się do okupowanego kraju. Podczas przekraczania granicy rumuńsko-sowieckiej zostali zatrzymani przez sowieckich pograniczników, aresztowani, a potem przewiezieni do Moskwy. Tutaj wyjawili swoje prawdziwe nazwiska, opowiedzieli o swojej wcześniejszej działalności wywiadowczej. Po wybuchu wojny niemiecko-sowieckiej NKWD zaproponowało im kontynuowanie współpracy, przerzut do okupowanej Polski oraz m.in. nawiązanie ponownego kontaktu z bratem. Żymierscy zgodzili się, 5 lipca 1941 r. uwolniono ich z więzienia, po czym rozpoczęli kurs wywiadowczy. Jednak podczas jednego z próbnych skoków spadochronowych Józef poważnie uszkodził nogę. Po podpisaniu układu Sikorski-Majski zostali skierowani do Wojska Polskiego. We wrześniu 1941 r. Stanisław Żymierski rozpoczął pracę w polskiej ambasadzie, a potem obaj znaleźli się w Armii Polskiej gen. Andersa. Wówczas o niektórych propozycjach składanych przez Sowietów w latach 1940-1941 Żymierscy mieli poinformować zarówno Józefa Retingera,jak i gen. Modelskiego oraz gen. Władysława Andersa. Według zeznań Stanisława, przed opuszczeniem Związku Sowieckiego, w Archangielsku, na przełomie grudnia 1941 i stycznia 1942 r. spotkał się z nim oficer sowieckiego wywiadu i przekazał „kontakt na 
tego ostatniego - Anny Buderackiej, dzięki której miał uzyskać kontakt z Michałem. Według zeznań składanych w latach pięćdziesiątych przez Matysiewicza nie otrzymał on z Moskwy żadnych oddzielnych zadań dla Żymierskiego, miał jedynie sprawdzić, czy „jest i jak się uplasował”. Matysiewicz po przybyciu do Warszawy na początku kwietnia 1942 r. przekazał list Buderackiej, która niezwłocznie zawiadomiła o tym Michała Żymierskiego ${ }^{85}$. Ten przybył do jej mieszkania, gdzie spotkał się z Matysiewiczem. Według tego ostatniego spotkanie było krótkie i miało następujący przebieg: „Buderacka oddała mu [Żymierskiemu - J. P.] przy mnie list i Żymierski stwierdził, że rzeczywiście pochodzi od brata. Ja wówczas powiedziałem do Żymierskiego, iż możliwe, że się jeszcze zobaczymy, ale na razie to wszystko. Po tym pożegnałem się"86. W 1942 r. to miało być ich jedyne wspólne spotkanie, nastąiła bowiem seria aresztowań w łonie PPR, gestapo odkryło radiostację, którą przywieźli ze sobą sowieccy agenci, a Matysiewicz musiał uciekać z Warszawy. Dzięki pomocy partyzantki sowieckiej udało mu się powrócić do Moskwy ${ }^{87}$. Żymierski natomiast w trakcie przesłuchania w 1955 r. twierdził, że kontakt z nieznanego mu powodu z Matysiewiczem urwał się dopiero we wrześniu $1942 r^{88}$ Oficjalne potwierdzenie działalności Żymierskiego na rzecz wywiadu z czasów jego pobytu w więzieniu w latach pięćdziesiątych informuje, że łączność z nim w 1942 r. ,została wznowiona i do 1945 r. Żymierski wykonywał poszczególne polecenia" 89 . Tak więc trudno jednoznacznie stwierdzić, czy było tylko jedno spotkanie Matysiewicza z Żymierskim. Ale nawet jeśli tak było, to stanowiło ono zapowiedź jego ponownej pracy agenturalnej. Nie wiemy, czy już wówczas dostał on jakieś wytyczne z Moskwy. Na pewno opowiedział

ambasadę radziecką w Londynie, z którą miałem utrzymywać łączność". Bardzo możliwe, że właśnie podczas tego spotkania Stanisław napisał list do swojego brata Michała, którym potem posługiwał się Matysiewicz. Jest to tym bardziej prawdopodobne, że Małecki z Matysiewiczem mieli zostać zrzuceni na teren okupowanego kraju jeszcze w styczniu $1942 \mathrm{r}$. Samolot z nimi na pokładzie nawet wystartował, jednak z powodu ostrzału niemieckiej obrony przeciwlotniczej zawrócił. Do udanego przerzutu doszło w marcu tego roku. Patrz: ASS MON, 161/91, t. 1447, Protokół przesłuchania Stanisława Żymierskiego, 24 VI 1954, oraz AAN, Zbiór akt osobowych działaczy ruchu robotniczego, 3787, Józef Małecki „Sęk”, Wspomnienia, t. 1,k. 92.

${ }^{85}$ AIPN, 2386/14730, Protokół przesłuchania Anny Buderackiej, 9 IV 1953, k. 44.

${ }^{86}$ AIPN, 2386/14714, Protokół przesłuchania Adolfa Matysiewicza, 23 II 1955, k. 131. Michał Żymierski zeznawał, że list był własnoręcznie napisany przez Stanisława i było w nim napisane, aby miał do Matysiewicza pełne zaufanie, jako do agenta sowieckiego wywiadu. Patrz: AIPN, 2386/14715, Protokół przesłuchania Michała Żymierskiego, 26 II 1955, k. 58.

${ }^{87}$ AIPN, 2386/14714, Protokół przesłuchania Adolfa Matysiewicza, 23 II 1955, k. 131.

${ }^{88}$ AIPN, 2386/14715, Protokół przesłuchania Michała Żymierskiego, 26 II 1955, k. 58.

${ }^{89}$ AIPN, 2386/14713, Notatka służbowa. Tłumaczenie z rosyjskiego danych zanotowanych przez gen. Karandaszewa, 6 VIII 1954, k. 226. 
o swojej dotychczasowej działalności konspiracyjnej, kontaktach z różnymi organizacjami podziemnymi, o wniknięciu w ich struktury, o ludziach z nim współpracujących. Mógł też mówić o kontaktach z niemiecką tajną policją. Zapewne starał się przekonać emisariusza z Moskwy o swoim dobrym „uplasowaniu” w Warszawie okupowanej przez Niemców. Nawet jeśli doszło do tylko jednego spotkania, to nawiązanie ponownego kontaktu z sowieckim wywiadem musiało być dla Żymierskiego bardzo istotne, wreszcie mogło nadać sens jego działalności konspiracyjnej. Dowiedział się, że nie zapomniano o nim w Moskwie i dano nadzieję na to, że będzie in spe potrzebny.

Matysiewicz po powrocie do Moskwy zdał relację z kontaktów z Żymierskim. Po pewnym czasie otrzymał rozkaz przygotowania się do wyjazdu do okupowanego kraju. W Warszawie znalazł się znów pod koniec kwietnia 1943 r. Wtedy nawiązał ponownie, już stały kontakt z byłym wojskowym. Matysiewicz zeznawał: „dostałem zadanie powrotu do kraju i nawiązania ścisłej współpracy z Żymierskim. Aby upewnić Żymierskiego, że może ze mną pracować, otrzymałem specjalne hasło do niego" ${ }^{90}$. Wraz z nim do Warszawy przybyła Janina Kirajew ${ }^{91}$, przyszła żona Matysiewicza. Kirajew miała obsługiwać radiostację, którą oboje przywieźli z Moskwy. Matysiewicz nawiązał także ponowny kontakt z Małeckim, który pracował w Sztabie Głównym GL. Ale pierwszym zadaniem, należy to podkreślić, była współpraca z Żymierskim. Spotkanie ich odbyło się ponownie w domu Buderackiej ${ }^{92}$. Matysiewicz wspominał: „Przywitał się, przepraszając za spóźnienie, rzucił kilka zdawkowych słów. [--] Wprowadzony w niektóre sprawy, nie wiedział, że pierwsza nasza wyprawa skończyła się niepowodzeniem, że musiałem powtórnie udać się do Moskwy, co siłą rzeczy spowodowało przerwę w naszych kontaktach". Kluczowe były jednak kolejne zdania: „Poinformowałem mojego rozmówcę, że w celu utrzymania łączności z centralą w Moskwie mam radiostację

${ }^{90}$ AIPN, 2386/14714, Protokół przesłuchania Adolfa Matysiewicza, 23 II 1955, k. 131.

${ }^{91}$ Janina Kirajew urodziła się w 1922 r. w Baranowiczach. Tutaj mieszkała do 1937 r., kiedy wyjechała do Związku Sowieckiego. Jeszcze podczas pobytu w Polsce związała się z ruchem komunistycznym, wstąpiła do Komunistycznego Związku Młodzieży Polskiej. W Moskwie przeszła szkolenie wywiadowcze i razem z Matysiewiczem została w kwietniu 1943 r. zrzucona do okupowanej Polski. Jako telegrafistka przesyłała meldunki dla wywiadu sowieckiego, wstąpiła też do GL i PPR. W 1945 r. pracowała w Wojewódzkim Urzędzie Bezpieczeństwa w Warszawie, a w latach 1946-1949 studiowała w Akademii Nauk Politycznych. Potem była m.in. dyrektorem administracyjnym w Państwowych Zakładach Wydawnictw Szkolnych, naczelnikiem wydziału w gabinecie ministra handlu zagranicznego (1953-1955). Patrz: CAW,1601/16/570, Akta personalne Janiny Matysiewicz z domu Kirajew.

${ }^{92}$ AIPN, 2386/14714, Protokół przesłuchania Adolfa Matysiewicza, 23 II 1955, k. 131. 


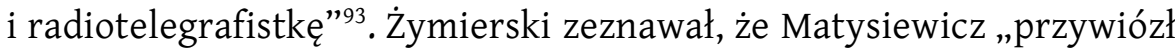
nowe instrukcje" 94 . Radiostacja została zakopana w miejscu zrzutu i należało przewieźć ją do Warszawy. Żymierski na pytanie o zaufaną osobę, która mogłaby pomóc to zrobić, wymienił Czermanowicza. Kirajew wraz z Czermanowiczem przetransportowali sprzęt do Warszawy i przez kilka pierwszych dni radiostacja funkcjonowała na Starym Mieście (Plac Zamkowy 9), w mieszkaniu tego ostatniego. Tutaj udało się nawiązać pierwszy kontakt z centralą. Jednak z powodu lepszych warunków do pracy wywiadowczej - mieszkanie Czermanowicza miało być także jednym z konspiracyjnych lokali Żymierskiego - radiostacja została przewieziona pod Warszawę, do Międzylesia. Na przełomie 1943 i 1944 r. przeniesiono ją do nieodległego Michalina, a w kwietniu 1944 nadawano z niej z Józefowa ${ }^{95}$. W ten sposób Żymierski otrzymał do dyspozycji radiostację, poprzez którą mógł utrzymywać stałą łączność z centralą w Moskwie.

W tym czasie Michał Żymierski przybrał pseudonim „Józef”. Matysiewicz wspominał, że utrzymywał z nim łączność różnymi kanałami. Początkowo przez Czermanowicza, ale ta droga szybko okazała się „niewygodna dla obu stron". Potem Żymierski zaproponował Matysiewiczowi spotkania w budce handlowej przy Żelaznej Bramie, a w dalszej kolejności także w mieszkaniu Żymierskich przy ul. Wspólnej. Ponadto Żymierski miał wyznaczać miejsca spotkań w kawiarni. Matysiewicz ,jak ognia" unikał miejsc publicznych, więc spotykali się przede wszystkim w mieszkaniach prywatnych. W jednym z fragmentów wspomnień Matysiewicz opisuje, że z czasem kontakty z Żymierskim przejęła na siebie Kirajew, która posługiwała się nazwiskiem Jadwiga Zakrzewska. Ona „doręczała i otrzymywała depesze do wysłania [do Moskwy - J.P.] oraz literaturę wydawaną przez organizacje - tak lewicowe, jak i wrogie nam, prawicowe, a nawet nieliczne o skłonnościach profaszystowskich". W innym miejscu precyzuje, że Kirajew wyręczała go tylko w mniej istotnych sprawach i wtedy spotykała się z Żymierskim w różnych lokalach, miejscach publicznych.Jako kobieta nie przyciągała „uwagi kręcących się tam szpicli” ${ }^{96}$. Niewiele więcej wiemy na temat informacji, jakie przekazywał Żymierski do centrali. Matysiewicz zeznawał w 1955 r., że Żymierski dostarczał materiały ogólnowojskowe, a raz miał informować o gen. Tadeuszu Borze-Komorowskim. Te ostatnie wiadomości miał przekazywać na „wyraźne żądanie Moskwy”97. Żymierski był prowadzony przez pułkownika NKWD-NKGB Tichona Szkołę-Szklarenkę

\footnotetext{
${ }^{93}$ A. Matysiewicz, Przez linię frontu, Warszawa 1983, s. 209-210.

${ }^{94}$ AIPN, 2386/14715, Protokół przesłuchania Michała Żymierskiego, 26 II 1955, k. 58.

${ }^{95}$ A. Matysiewicz, op.cit., s. 209-215.

${ }^{96}$ Ibidem, s. 225, 234.

${ }_{97}$ AIPN, 2386/14714, Protokół przesłuchania Adolfa Matysiewicza, 23 II 1955, k. 131.
} 
(Tihon Tihonovič Škola-Šklârenko), późniejszego łącznika pomiędzy sowieckim wywiadem na ziemiach polskich a organami MBP ${ }^{98}$. Matysiewicz o swojej działalności w konspiracji i kontaktach z Moskwą we wspomnieniach pisał, że przekazywał wiadomości „o sytuacji w tzw. Generalnym Gubernatorstwie, o nastrojach ludności, stanowisku społeczeństwa wobec Niemców, o rozmiarach terroru, rozstrzeliwaniach, warunkach ekonomicznych, ugrupowaniach i partiach politycznych, o ich kierunkach ideowych i wielu podobnych sprawach" ${ }^{99}$. Na pewno wiele z tych informacji pochodziło od Żymierskiego.

Istniał jednak jeszcze jeden cel nawiązania kontaktu przez Żymierskiego z Moskwą. Z centrali otrzymał on polecenie skontaktowania się z przedstawicielami GL i PPR oraz wstąpienia do organizacji bojowej polskich komunistów. Władysław Gomułka w swoich wspomnieniach pisze, że to właśnie wywiad sowiecki „przekazał” Żymierskiego komunistom ${ }^{100}$. Przyszły komunistyczny marszałek zeznawał w latach pięćdziesiątych, że poprosił Matysiewicza o skontaktowanie go „z partią"101. Potwierdzał to także Matysiewicz - Żymierski zgłosił się do niego z prośbą o rozmowę z członkami GL. Ten przedstawił propozycję Małeckiemu, nie ujawniając nazwiska Żymierskiego ${ }^{102}$. Małecki wspominał pierwsze spotkanie z Żymierskim: „Spotkaliśmy się w niedzielę nad Wisłą. Po dłuższej rozmowie pierwsze wiadomości zostały potwierdzone i sprawiły mi dużą niespodziankę. Człowiekiem tym okazał się gen. Michał Żymierski, którego oczywiście znałem z opisów [- - ]. Potwierdził on to wszystko, co już wiedzia-

98 P. Kołakowski, Pretorianie Stalina. Sowieckie służby bezpieczeństwa i wywiadu na ziemiach polskich 1939-1945, Warszawa 2010, s. 378. Jeden z agentów sowieckiego wywiadu, Artur Ritter-Jastrzębski, przekazujący informacje podobnie jak Żymierski z Warszawy, latem 1944 r. spotkał się w Otwocku z płk. Szklarenką, o którym rzekł: „Doskonale orientował się w sytuacji politycznej i wojskowej w Warszawie. Kiedy zapytałem go, skąd ma tak bezbłędną znajomość realiów warszawskich, usłyszałem coś w rodzaju komplementu, że właśnie poznał ją z naszych meldunków”. Na pewno przyczyniła się do tego także działalność Żymierskiego. Patrz: A. Jastrzębski, Życie na krawędzi, w: Życie na krawędzi. Wspomnienia żołnierzy antyhitlerowskiego wywiadu, Warszawa 1980, s. 106.

${ }_{99}$ A. Matysiewicz, op. cit., s. 230.

100 W. Gomułka, Pamiętniki, t. 2, Warszawa 1994, s. 373. J. Światło w czasie audycji w Radio Wolna Europa mówił, że „z polecenia wywiadu sowieckiego Żymierski został dowódcą AL". W dokumentach ze śledztwa nie jest to w sposób jednoznaczny powiedziane. Oczywiście wiele do myślenia daje moment, w którym Żymierski podjął rozmowy z PPR i GL - niedługo po przybyciu do Warszawy dwóch sowieckich agentów Matysiewicza i Małeckiego, którzy znaleźli się w strukturach GL, a także niedługo po nawiązaniu przez Żymierskiego kontaktu z Moskwą. Z. Błażyński, op. cit., s. 52-53.

${ }^{101}$ AIPN, 2386/14715, Protokół przesłuchania Michała Żymierskiego, 26 II 1955, k. 59.

${ }^{102}$ Tutaj zeznania Żymierskiego nieco się różnią. On tłumaczył, że pierwszą osobą z GL, którą spotkał, był Franciszek Jóźwiak „Witold”, szef sztabu GL. Patrz: AIPN, 2386/14715, Protokół przesłuchania Michała Żymierskiego, 26 II 1955, k. 59. 
łem, a więc chęć wstąpienia do GL [-- ]. Byłem zaskoczony otwartością i jasnym stawianiem sprawy, podania nazwisk i sposobów kontaktowania się z nim. Wyraził on życzenie spotkania się z kierownictwem wojskowym GL i politycznym"103. Jak widać, doświadczony wywiadowca Żymierski wiedział, czego chce. Małecki skontaktował się z szefem sztabu GL Franciszkiem Jóźwiakiem „Witoldem” ${ }^{104}$, który po kilku dniach przekazał mu polecenie znalezienia odpowiedniego mieszkania i ustalenia daty spotkania z Żymierskim. Do spotkania takiego doszło w konspiracyjnym mieszkaniu przy ul. Dobrej 37. Obok zainteresowanego uczestniczyli w nim sekretarz PPR Paweł Finder oraz „Witold” i Małecki. Nad bezpieczeństwem czuwał Matysiewicz, gości przyjmowała zaś, pełniąc „honory domu”, Kirajew. Matysiewicz wspominał, że przygotowano na obiad kotlety z koniny, a wszyscy byli „zachwyceni przyjęciem, podziwiali zdolności kulinarne Jany [Janiny Kirajew - J.P.], tylko gen. Żymierski, znawca kuchni, powiedział, że wprawdzie dawno tak dobrych kotletów nie jadł, ale uważa, że były trochę za pulchne"105. Oczywiście nie o kotlety tutaj chodziło. Małecki nie pamiętał dokładnie treści rozmowy, jednak w 1955 r. zeznawał, że Żymierski opowiadał Finderowi i „Witoldowi” m.in. o swojej działalności w Związku Podoficerów Rezerwy i możliwości podporządkowania organizacji GL, o znajomościach i sytuacji w $\mathrm{AK}^{106}$. Podczas spotkania zdecydowano, że Żymierski włączy się w działalność komunistycznego podziemia. Uczyniono go doradcą wojskowym GL. W ten sposób przestał być „tylko” wywiadowcą sowieckim, znalazł się także w podziemnych strukturach organizacji, która jak się okazało, z ramienia Moskwy miała niedługo przejmować władzę w kraju.

Żymierski otrzymał odpowiednie polecenie z Moskwy, ale także w GL i PPR odebrano instrukcje mówiące o tym, co czynić z nowym członkiem. Gomułka z Żymierskim spotkał się osobiście dopiero w grudniu 1943 r.,jednak już wiosną Finder rozmawiał z nim o przyjęciu Żymierskiego do GL.

${ }^{103}$ AAN, Zbiór akt osobowych działaczy ruchu robotniczego, 3787, Józef Małecki „Sęk”, Wspomnienia, t.2, k.139. Relacje Małeckiego i Matysiewicza nieco różnią się od siebie. Małecki wspominał, że przed pierwszym spotkaniem z Żymierskim nie informował nikogo z GL, Matysiewicz zaś uważa, że Małecki jeszcze przed tym spotkaniem konsultował sie z „Witoldem”.

104 „Witold” pełnił wówczas funkcję szefa sztabu GL, po zabójstwie Bolesława Mołojca nieobsadzone było natomiast stanowisko dowódcy tej organizacji. Jóźwiak miał aspiracje, aby takie stanowisko objąć, jednak zarówno Gomułka, jak i Spychalski uważali, że nie miał on odpowiedniego fachowego przygotowania do pełnienia takiej funkcji. Ponadto popadł on w poważny konflikt z Ignacym Robbem „Narbuttem”, a także Spychalskim, dotyczący funkcjonowania organizacji. Patrz: W. Gomułka, op. cit., t. 2, s. 372-373.

${ }^{105}$ A. Matysiewicz, op. cit., s. 228-229.

${ }^{106}$ AIPN, 2386/14714, Protokół przesłuchania Józefa Małeckiego, 24 II 1954, k. 138. 
Gomułka był przekonany, że wobec ścisłego kontaktu, jaki utrzymywał sekretarz PPR z Georgim Dimitrowem, sekretarzem generalnym Kominternu, jasne było, że „Żymierskiego - jak wspominał Gomułka — oddał nam wywiad radziecki, by wykorzystać go jako oficera w stopniu generalskim do pracy w Sztabie Głównym GL. Wobec wielkiego niedostatku wykwalifikowanej kadry oficerskiej [- - ] w całej naszej organizacji wojskowej, nabytek ten uważałem, podobnie jak Finder, za bardzo cenny" ${ }^{107}$.

Żymierski pracował od tego momentu w oddziale wyszkoleniowym i operacyjnym GL. Małecki otrzymał rozkaz oddania do dyspozycji późniejszego komunistycznego marszałka dwóch lokali, do których dostarczał materiały konspiracyjne ${ }^{108}$. Marian Spychalski, wówczas zastępca szefa Sztabu Głównego GL, a jednocześnie szef wywiadu organizacji, po raz pierwszy spotkał się z Żymierskim latem 1943 r. Według zeznań złożonych przez niego w 1953 r. przed śledczymi w związku ze sprawą „odchylenia prawicowo-nacjonalistycznego" w partii i wojsku Żymierski przybył wówczas po raz pierwszy na posiedzenie sztabu GL i wygłosił referat o strukturze władz wojskowych w II Rzeczypospolitej ${ }^{109}$. Na spotkaniu obecni byli „Witold”, Małecki „Sęk” oraz inni członkowie sztabu: Ignacy Robb „Narbutt”, Franciszek Księżarczyk i prawdopodobnie Ignacy Loga-Sowiński ${ }^{110}$. Żymierski w tym też okresie poznał Bieruta, z którym skontaktował go „Witold”, natomiast w miesiącach jesiennych 1943 r. uchwałą sekretariatu Komitetu Centralnego PPR został włączony w skład Sztabu Głównego GL ${ }^{111}$. Spychalski zeznawał, że jeśli chodzi o działalność w organizacji, to Żymierski pozostawał w stałym kontakcie z „Witoldem", uczestniczył w posiedzeniach sztabu, na których omawiano działalność operacyjno-wyszkoleniową organizacji. Wówczas Żymierski miał podnosić m.in. sprawy organizacyjne aparatu centralnego GL, oddziałów terenowych, na ogół ograniczał się do zagadnień wojskowych. Charakteryzując jego wystąpienia, mówił, iż „zaznaczało się, że starał się wydobyć on swój autorytet w tych zagadnieniach"112.

W listopadzie 1943 r. komuniści zdecydowali się powołać KRN, wydano także dekret o utworzeniu Armii Ludowej. Zarówno KRN, jak i AL miała poszerzać reprezentację polityczną społeczeństwa polskiego, w praktyce KRN

${ }^{107}$ W. Gomułka, op. cit., t. 2, s. 373.

108 AIPN, 2386/14714, Protokół przesłuchania Józefa Małeckiego, 24 II 1954, k. 138.

109 AIPN, 2386/14728, Protokół przesłuchania Mariana Spychalskiego, 5 V 1953, k. 211.

${ }^{110}$ AAN, 509/115, Oświadczenie R. Narbutta w sprawie działalności z grupą prawicowo-nacjonalistyczną Gomułki, 10 III 1951, k. 18.

111 W. Gomułka, op. cit., t. 2, s. 374.

112 AIPN, 2386/14728, Protokół przesłuchania Mariana Spychalskiego, 5 V 1953, k. 211-212. 
składała się oprócz PPR z organizacji podporządkowanych komunistom, albo nic nieznaczących w działalności podziemnej ${ }^{113}$. Natomiast w przypadku AL zmieniono tylko szyld, jedyną poważną różnicą względem GL było powołanie nowego dowódcy. Został nim właśnie Żymierski. Nie obyło się jednak bez kontrowersji. Od czas zabójstwa Bolesława Mołojca w grudniu 1942 r. GL nie miała swojego dowódcy. Teoretycznie na jej czele stał „Witold”, jako szef sztabu, jednak brak kwalifikacji „Witolda” do pełnienia tych funkcji znany był powszechnie w kierownictwie komunistów. Nie miał on żadnego doświadczenia wojskowego - swoją służbę w wojsku zakończył w stopniu kaprala w Legionach Polskich. Dodatkowo był mocno skonfliktowany z częścią kierownictwa PPR i komunistycznej partyzantki. Mimo wszystko szef sztabu miał ambicje kierowania nie tylko GL i AL, ale także w przyszłości całym wojskiem zależnym od komunistów ${ }^{114}$. Jeszcze przed utworzeniem AL „Witold” próbował podkopać kandydaturę Żymierskiego - nie widział celowości powołania nowej organizacji i w ten sposób dążył do pozostawienia GL pod swoim formalnym przywództwem. W tym też czasie nastąpiły poważne zmiany w łonie PPR - w listopadzie $1943 \mathrm{r}$. gestapo aresztowało jej sekretarza generalnego, Findera, oraz członkinię KC Małgorzatę Fornalską, która utrzymywała łączność radiową z Moskwą. W ten sposób bez kontaktu z centralą utworzono zarówno KRN, jak i AL oraz - co miało poważne konsekwencje - wybrano Gomułkę na nowego szefa partii. Nowe kierownictwo partii nie podzieliło wątpliwości „Witolda" w sprawie powołania AL. Kluczowy w tej sprawie był fakt wysunięcia Żymierskiego na dowódcę AL przez Findera (jeszcze przed jego aresztowaniem), który najpewniej otrzymał takie wytyczne od Dimitrowa ${ }^{115}$.

Jak zeznawał w 1953 r. Spychalski, Żymierski w listopadzie albo w grudniu w sztabie GL przedstawił „projekt uzasadnienia powołania Armii Ludowej i jej dowództwa". Natomiast na pierwsze zebranie KRN, w sylwestrową noc 1943 r. w mieszkaniu przy Twardej 22, Żymierskiego miał wprowadzać $\mathrm{z}$ ulicy właśnie Spychalski ${ }^{116}$. W trakcie obrad przyjęto uchwałę powołującą AL. Jerzy Fonkowicz wspominał, że przewodniczący zebraniu Bierut podał kandydaturę gen. Roli na naczelnego dowódcę AL.

113 P. Gontarczyk, PPR. Droga do władzy 1941-1944, Warszawa 2003, s. 306-318.

${ }^{114}$ W swoich pamiętnikach Gomułka pisał, że Jóźwiak ,jako szef Sztabu Głównego AL miał [- - ] rangę generała i chyba to zwichnęło logikę jego rozumowania kategoriami wojskowymi. Toteż w dyskusji, chcąc uprzytomnić mu jego kwalifikacje wojskowe, zapytałem nieco złośliwie: «Franek, czy ty rzeczywiście uważasz, że jako szef Sztabu Armii Ludowej kwalifikujesz się na szefa Sztabu Głównego Wojska Polskiego?». Nie zareagował, czyli nie zdołałem sprowadzić go z obłoków na ziemię". Patrz: W. Gomułka, op. cit., t. 2, s. 427.

115 W. Gomułka, op. cit., t. 2, s. 374-375.

116 AIPN, 2386/14728, Protokół przesłuchania Mariana Spychalskiego, 5 V 1953, k. 212. 
Odczytano jego krótki życiorys i opis działalności. Kandydaturę przyjęto jednogłośnie. Nikt z obecnych nie wiedział, że gen. Rola pod zmienionym pseudonimem (wcześniej posługiwał się pseudonimem „Józef”) bierze udział w obradach. Ustalono i zatwierdzono skład naczelnego dowództwa AL, złożonego z trzech osób: naczelnego dowódcy, szefa sztabu i przedstawiciela KRN ${ }^{117}$. Pseudonim „Rola” miał wymyślić Spychalski, który uzasadniał wzmocnieniem przez to czynnika chłopskiego w AL. Podczas spotkania nikt nie był przeciwko, a Żymierski miał nawet podchwycić jego inicjatywę „bardzo gorliwie”"118.

Żymierski został dowódcą komunistycznej partyzantki, ponieważ był doświadczonym oficerem zawodowym, przedwojennym generałem, co prawda kryminalistą, jednak uchodzącym w niektórych środowiskach za ofiarę konfliktu z Piłsudskim. Miał też kolejną, ważną zaletę - był jedyną postacią z rozpoznawalnym nazwiskiem spośród całego kierownictwa komunistycznego podziemia. W odbiorze społecznym, a przecież komuniści przygotowywali się do objęcia władzy w Polsce, dużo więcej znaczył niż choćby nieznany nikomu „Witold”. Ale kluczowe było to, że na stanowisko dowódcy AL został wysunięty przez Moskwę - jako zaufany NKWD.

Jaką zajmował pozycję w komunistycznej hierarchii w okupowanym kraju? Żymierski nie znajdował się w „grupach inicjatywnych” wysyłanych z Moskwy, nie zakładał partyzantki komunistycznej, a do GL trafił dosyć późno. Mógł zostać wykorzystany w działaniach organizacyjnych, ściśle wojskowych, a także propagandowych - oczywiście początkowo w ramach konspiracyjnych możliwości. Nie on był jednak kluczowym rozgrywającym. Wynika to choćby ze składanych przez Spychalskiego zeznań w 1953 r. Ten ostatni mówił wówczas, że co prawda Żymierski, będąc już na stanowisku dowódcy AL, starał się dowiedzieć, w jaki sposób pracowały podległe Spychalskiemu komórki, a więc wywiad i redakcja „Gwardzisty”, organu prasowego GL/AL, jednak Spychalski przekazywał mu tylko ogólne informacje organizacyjne, nawet bez wyszczególniania pseudonimów. Mówił ponadto, że „pozycja Żymierskiego była w GL, a następnie w AL, tak ustawiona, że nie był on wprowadzany w konkretne zagadnienia organizacyjne”, a Żymierski znowu „nie wykazywał dążenia do pogłębienia zakresu udzielanych mu informacji"119.

${ }^{117}$ J. Fonkowicz, Pierwsze pistolety, Warszawa 1965, s. 158-172.

118 AIPN, 2386/14728, Protokół przesłuchania Mariana Spychalskiego, 5 V 1953, k. 212.

${ }^{119}$ Ponadto Spychalski zeznawał, że ich wzajemne stosunki miały być poprawne. Żymierski nawet proponował, by przeszli na „ty”, Spychalski jednak nie zgodził się na to. AIPN 2386/14728, Protokół przesłuchania Mariana Spychalskiego, 5 V 1953, k. 213. 
Należy przy tym zwrócić uwagę na różnicę dotyczącą określania przez Żymierskiego i Spychalskiego swoich możliwości decyzyjnych w GL/AL i w wojsku powojennym. Podczas całego pobytu w więzieniu w latach pięćdziesiątych zarówno Spychalski, jak i Żymierski umniejszali swoją rolę w kierowaniu wojskiem po wojnie, choćby przerzucali na siebie nawzajem odpowiedzialność za prowadzenie polityki kadrowej. W zeznaniach dotyczących działalności w czasie okupacji niemieckiej Spychalski swojej roli nie umniejszał, dosyć jednoznacznie za to wskazywał poślednią pozycję Żymierskiego w pracach GL/AL. Odzwierciedleniem rangi Żymierskiego w strukturach podziemnej władzy zależnej od Moskwy są też jego wypowiedzi o podporządkowaniu dowództwa AL. Wspominał: „,w AL bardzo pilnie przestrzegano utrzymania prymatu partii w wojsku. W sprawach politycznych decydowało nie dowództwo wojskowe, ale partia, i wojsko było podporządkowane partii. Formalnie podporządkowane KRN, ale ideowo, politycznie i organizacyjnie było podporządkowane partii i Komitetowi Centralnemu". Żymierski nie był członkiem KC PPR, na którego posiedzeniach decydowano o najważniejszych sprawach czy też wprowadzano w życia dyrektywy płynące z Moskwy. Członkiem KC był natomiast „Witold”. Żymierski wspominał: „Byliśmy zdania, że wszystko to, co dzieje się na prezydium KRN, jest uzgodnione uprzednio z KC. Tym człowiekiem, który miał to uzgadniać, był tow. Bierut. Tow. Bierut nie mógł postawić sprawy na KRN-ie, jeżeli nie uzgodnił [jej] uprzednio z KC”. Żymierski był „przedstawicielem Armii Ludowej w KRN-ie, a Jóźwiak był przedstawicielem w KC. Obowiązkiem Jóźwiaka było informować KC i Gomułkę o wszystkich poczynaniach wojska i zarządzeniach, które robimy, ja byłem zobowiązany informować prezydium KRN o tym, co się dzieje w Armii Ludowej i w wojsku" 120 . Tak więc formalnie Żymierski był przełożonym „Witolda” i Spychalskiego, jednak we władzach partii mieli oni silniejszą pozycję. Trudno też określić jego stosunek do konfliktu w sztabie GL/AL pomiędzy „Witoldem” i Spychalskim. Żymierski wspominał, że miał on dobry kontakt zarówno z jednym, jak i drugim. Spychalski natomiast nie mógł przypomnieć sobie stanowiska Żymierskiego w tej sprawie ${ }^{121}$. Może po prostu nie było ono znaczące dla stosunków wewnątrz komunistycznej partyzantki. Wydaje się, że sytuacja Żymierskiego niewiele różniła się od tej,jaką miał w powojennym wojsku - zależny był od kierownictwa PPR, ta znów od instrukcji płynących z Moskwy. Nie on decydował o kształcie ideowym

${ }^{120}$ AAN, Zbiór akt osobowych działaczy ruchu robotniczego, 6840, Michał Rola-Żymierski, pkt. 2, Powstanie i działalność KRN. Relacja marszałka Michała Roli-Żymierskiego nagrana 31 I 1959, k. 10-11.

${ }^{121}$ AIPN, 2386/14728, Protokół przesłuchania Mariana Spychalskiego, 5 V 1953, k. 213. 
konspiracyjnego wojska, mógł jedynie wpływać na sprawy organizacyjne czy też pisać instrukcje wojskowe.

Po powstaniu AL na wszystkich rozkazach wydawanych przez Dowództwo Główne obok podpisu „Witolda, jako dowódcy sztabu AL, widniał podpis „Rola”. Tak było do czerwca 1944 r., gdy Żymierski został wysłany z drugą delegacją KRN do Moskwy ${ }^{122}$. Polecenie wyjazdu do stolicy ZSRS przekazał mu Matysiewicz: „Depesza mówiąca o jego wyjeździe do Moskwy była tylko do jego osobistej wiadomości”. Potem przyszła kolejna, już oficjalna do kierownictwa PPR i na jej podstawie, w połowie czerwca, na prezydium KRN zapadła decyzja o przerzuceniu delegacji z Żymierskim na czele do Związku Sowieckiego ${ }^{123}$. Dowódca AL przed wyjazdem pożegnał się z żoną i polecił jej wyprowadzić się z Warszawy. Żymierska dostała kenkartę wystawioną na nazwisko Helena Zielińska. Zamieszkała wraz z córką we wsi pod Jabłonną. Żymierski powiedział jej też, aby po wkroczeniu Armii Czerwonej zwróciła się do jakiegokolwiek oficera sowieckiego, a wtedy będzie „odtransportowana do męża" ${ }^{124}$. Wybuch powstania warszawskiego skomplikował te zamiary. Żymierska została wysiedlona i znalazła się w Częstochowie. Jej mąż powrócił do Warszawy w nowej poważnej roli. W lipcu 1944 r. został naczelnym dowódcą wojska podporządkowanego komunistom, pełnił funkcję kierownika resortu obrony narodowej, najpierw w Polskim Komitecie Wyzwolenia Narodowego, potem do 1949 r. był ministrem w kolejnych rządach. Jeszcze w maju 1945 r. mianowano go marszałkiem Polski.

122 Pierwsza delegacja KRN ze Spychalskim oraz Edwardem Osóbką-Morawskim na czele została wysłana w marcu 1944 r. do Moskwy w celu wyjaśnienia kontrowersji narosłych pomiędzy polskimi komunistami w kraju a Centralnym Biurem Komunistów Polski i centralą w Moskwie. Z powodu różnych perturbacji znalazła się tam dopiero 16 maja. W skład drugiej delegacji KRN, która udała się do Moskwy, wchodzili obok Żymierskiego Stanisław Kotek-Agroszewski oraz Jan Czechowski.

${ }^{123}$ A. Matysiewicz, op. cit., s. 244. Żymierski nie mówił w swoich wspomnieniach o wezwaniu do wyjazdu płynącym z Moskwy. Jednak zauważał, że najpierw decyzja o wyjeździe została zaakceptowana przez KC, dopiero potem przez KRN. AAN, Zbiór akt osobowych działaczy ruchu robotniczego, 6840, Michał Rola-Żymierski, pkt. 2, Powstanie i działalność KRN. Relacja marszałka Michała Roli-Żymierskiego nagrana 31 I 1959, k. 13. Gomułka zaś pisał o „przyjęciu przez kierownictwo partii sugestii Stalina w sprawie rozszerzenia składu delegacji KRN przebywającej w Związku Radzieckim", W. Gomułka, op. cit., t. 2, s. 426.

124 AIPN, 2386/14728, Protokół przesłuchania Zofii Żymierskiej, 15 III 1953, k. 79 oraz A. Matysiewicz, op. cit., s. 244. 


\section{The Activity of Michał Żymierski during the German Occupation in the Light of the Records of the Ministry of Public Security}

The article was based on material used by officers of the Ministry of Public Security and the Main Directorate of Information of the Polish Army during the 1950s in connection with a struggle waged against the so-called rightist-nationalist deviation in the Party and the Army. One of the chief examined motifs was an attempt at establishing the nature of the activity pursued by Żymierski at the time of the German occupation. Apparently, from the very onset Żymierski maintained steady contacts with German secret agents in Warsaw. Other symptoms indicate that he could have established contacts with officers of the German secret police. During the first years of the occupation Żymierski tried to take an active part in the Polish Underground but initially found himself on the margin of conspiracy work (as the head of the Reserve officers' Association); with time, he also made contacts with members of larger conspiracies, such as "Miecz i Pług" (Sword and Plough). In addition, Żymierski attempted to join the main current of the Polish Underground and become a member of Związek Walki Zbrojnej/Armia Krajowa (Union for Armed Struggle/Home Army). In the spring of 1942 the future communist marshal renewed his links with the Soviet Intelligence for which he had worked already in the 1930s. Until 1945 he sent from the occupied Polish capital information concerning acquaintances in political and military Underground organisations. The Soviet Intelligence headquarters in Moscow used him for work in the communist underground military organisation - Gwardia Ludowa (People's Guard - GL); on 1 January 1944 Żymierski became head of GL's successor Armia Ludowa (People's Army). In this manner, he found himself within a small group of communist activists who after the war seized power in Poland.

Translated by Aleksandra Rodzińska-Chojnowska 